\title{
CRISE DA RAZÃO NO MUNDO CONTEMPORÂNEO: AS (PÓS-MODERNAS) TENDÊNCIAS DE SUPERAÇÃO DA RAZÃO TECNO-INSTRUMENTAL E DO PARADIGMA LIBERAL UNIVERSALISTA (OLHAR PARA TRÁS É OLHAR PARA O FUTURO? $)^{1}$
}

\author{
Fernando TORRÃO \\ Professor Faculdade de Direito \\ Universidade Lusíada do Porto \\ ftorrao@por.ulusiada.pt
}

\begin{abstract}
RESUMEN
Neste estudo promove-se uma reflexão (de cariz essencialmente filosófico-político) acerca da superação do paradigma liberal racional (que foi caracterizando o modo de pensar Ocidental durante a Idade Moderna desde a Ilustração de setecentos) pelo despontar de uma nova era, a era (por muitos chamada de) pós-moderna, que, através do método desconstrucionista, refuta as grandes narrativas do passado, relativizando «verdades» tidas como absolutas. Mas será efetivamente um avanço civilizacional aclamar, na esteira de Horkheimar, o «eclipse da razão»?
\end{abstract}

Palabras clave: liberalismo, razón, posmodernidad, universalidad.

\section{ABSTRACT}

We advocate through this piece of work a mainly philosophical-political reflection onto the overcoming of the rational liberal model which characterized the Western way of thinking in the Modern Age (from the Age of Enlightenment onward), caused by the dawn of -as many put it-postmodern times, which, through deconstructionist methods reject the great narrative from the past, diminishing the importance of the supposedly absolute «truths». However, is it truly a step forward of civilization to proclaim -following Horkheimars footsteps- or the «decline of reason»?

Keywords: Liberalism, Reason, Postmodernity, Universality.

${ }^{1}$ Interrogação inspirada nas correntes que olham a História através de movimentos cíclicos tão bem sintetizadas na expressão «looking back to the future» encontrada no título da obra de Griselda Pollock publicada em 2001, à qual Paulo de Sousa Mendes faz referência utilizando essa mesma expressão (cfr. P. de S. MENDES, O torto intrinsecamente culposo como condição necessária da imputação da pena, Coimbra, Coimbra Editora, 2007, p. 33). 


\section{ZUSAMMENFASSUNG}

Mit diesem Aufsatz soll eine Reflexion (mit wesentlich philosophisch-politischem Charakter) vorangetrieben werden, die sich die Überwindung des liberal-rationalen Paradigmas (das die westliche Denkweise der Moderne seit der Aufklärung geprägt hat) zum Ziel gesetzt hat. Diese Epoche wurde abgelöst durch die neue Ära (die von vielen) als die Postmodere bezeichnet wird und die durch die Methode des Dekonstruktivismus große Geschichtserzählungen der Vergangenheit ablehnt und die «absoluten»Wabrheiten relativiert. Aber wäre es wirklich ein Zivilisationsfortschrift, dem vorgezeichneten Weg Max Horkheimers folgend, den «eclipse of reason» zu proklamieren?

Schlüsselwörter: Liberalismus, Vernunft, Postmodernismus, Universalität.

SUMARIO: I. INTRODUÇÃO.--II. A SITUAÇÃO MUNDIAL CONTEMPORÂNEA E O PARADIGMA RACIONAL (NEO??)LIBERAL.-III. POPPER E A FALIBILIDADE DA RAZÃO (TEÓRICA E PRÁTICA).-IV. A NECESSIDADE, NÃO OBSTANTE, DE UM PARADIGMA DE BASE RACIONAL.-V. A LIÇÃO DE STUART MILL, A (POSSÍVEL) UTILIDADE SOCIAL DA RAZÃ̃ CALCULADORA E O NEOCONTRATUALISMO DE RAWLS.-VI. QUAL O FUTURO DA FILOSOFIA POLÍTICA? O LIBERALISMO ENQUANTO «FIM DA HISTÓRIA» (FUKUYAMA) OU UM (PÓS-MODERNO) REQUIEM PELO PARADIGMA ILUMINISTA? OLHAR A PÓS-MODERNIDADE É OLHAR A PRÉ-MODERNIDADE?-VII. BIBLIOGRAFIA.

\section{INTRODUÇÃO}

A filosofia política contemporânea é marcada, em muito, pelas incertezas e flagelos da chamada «sociedade de risco» (Risikogesellschaft) — tópico colocado em evidência por Ulrich Beck - considerada, amiúde, produto da hegemonia de um racionalismo moderno de fisionomia utilitarista no qual desponta a razão tecno-instrumental vertida em razão «coisificadora, orientada essencialmente pelo interesse de domínio» (Anselmo de Borges) do ser humano sobre o «outro» e sobre a natureza. No diagnóstico da «sociedade de risco» é destacada a circunstância de os benefícios da tecnociência comportarem o seu reverso, ou seja, acarretarem dúvidas, descontinuidades e incertezas provindas de perigos de extrema gravidade com potencial dimensão planetária. Alude-se, $v$. g., a situações como o flagelo dos desastres ambientais, o drama das contaminações alimentares, as confusas alterações climáticas ou a tragédia do terrorismo global para evidenciar o destino que a Humanidade vai traçando a si própria. Assacadas responsabilidades à «razão moderna» vocacionada para o domínio da 
natureza e para a anulação do «outro», gera-se a crise do liberalismo e o esboroar das grandes narrativas de base racionalista.

São, por isso, muitos os que vão proclamando o ideal de superação do paradigma liberal racional de base contratualista, cujas raízes se buscam, essencialmente, no jusnaturalismo de seiscentos e na Ilustração de setecentos e que foi caracterizando o modo de pensar da Idade Moderna. Para assinalar a rutura com o racionalismo moderno, evoca-se o despontar de uma nova era, a era pós-moderna, que, através do método desconstrucionista, refuta as grandes narrativas do passado, supostamente universais, relativizando «verdades» tidas como absolutas. O pós-modernismo corresponde, neste sentido e em traços gerais, a um modo de perspetivar a realidade contemporânea pelo qual deixa de alcandorar-se a razão a motor central da existência. Aclama-se, na esteira de Horkheimer, o «eclipse da razão».

Em causa se coloca, deste modo, o paradigma liberal iluminista - legitimado, essencialmente, no modelo do contrato social- edificador das traves mestras da filosofia política que tem dominado o mundo ocidental nos últimos séculos e sobre as quais se alicerçam as chamadas democracias liberais. E se este é um paradigma que resistiu aos ventos do Estado Social, constituindo-se como núcleo essencial (defensivo-negativo) da fórmula do Estado de Direito materialmente democrático e social (que não prescinde, desse jeito, da sua matriz liberal), agora, com o advento do «Estado pós-Social», vai sendo propalada (ou apressada), em muitos setores do mundo contemporâneo, a sua definitiva desconstrução e consequente superação (supressão).

\section{A SITUAÇÃO MUNDIAL CONTEMPORÂNEA E O PARADIGMA RACIONAL (NEO?)LIBERAL}

A propósito do tópico da «sociedade de risco» —e a intento do futuro da Humanidade - muitos dos temas essenciais que se vão debatendo em variados campos do saber e em diversas latitudes do mundo atual desaguam na problemática de se saber, afinal, se é viável a própria existência do género humano no planeta. Num enfoque superficial e pouco atento, esta poderia até parecer uma problemática confinada a alguns setores do pensamento contemporâneo vocacionados para o exagero como é característico daqueles que acusam uma desmedida propensão para uma qualquer sorte de «securitarismo alarmista» e que seriam apoiados por meios 
de comunicação social ávidos de profecias catastróficas como é tão característico desta nossa (como alguém já qualificou) Idade dos Media. Mas se é verdade que estas circunstâncias são próprias do nosso tempo, elas não devem obnubilar os perigos efetivos. $\mathrm{Na}$ verdade, numa análise atenta e ponderada, torna-se realmente difícil negar que muitas das contingências do mundo atual vão colocando em risco a vivência humana no planeta. E ainda que sobre todos paire a ameaça dos efeitos potencialmente catastróficos desta sociedade de risco, na medida em que estes assumem uma dimensão mundial, não deixa também de ser verdade que são as zonas economicamente mais desfavorecidas do normalmente designado terceiro mundo as primeiras a sentir esses efeitos, contribuindo para que se ampliem, ainda mais, as desigualdades a vários níveis. Trata-se, de resto, de um fenómeno encarado com uma forte dose de fatalismo no momento histórico atual, porquanto a lógica do homo oeconomicus favorece a deslocalização das indústrias dos países mais desenvolvidos para os países com mais baixos custos de produção. E este fenómeno tanto mais se agrava quanto mais se verifica que são as indústrias de superior risco tóxico para o ser humano as que mais tendem para essa deslocalização. Não aludimos, obviamente, a uma pura casualidade; ao cálculo económico junta-se, pois, o cálculo da distribuição dos riscos, podendo, desta feita, perceber-se a existência de «una «fuerza de atracción» sistemática entre la probreza extrema y los riesgos extremos» ${ }^{2}$, força de atracção esta que é ainda favorecida pela receptividade das populações subdesenvolvidas. É que as refinarias e as fábricas químicas criam emprego, levando a que o proletariado da sociedade (mundial) de risco as aceite com satisfação, generalizando-se uma profunda cegueira no que toca à real dimensão dos riscos por elas desencadeados. Mais uma vez se manifesta a analogia histórica com algumas das vicissitudes próprias do ciclo da Revolução Industrial, ainda que as vicissitudes actuais, como é natural, assumam uma escala de feição globalizante. Os exércitos de reserva industrial situam-se agora, pois, em várias zonas do globo, normalmente coincidentes com regiões subdesenvolvidas, potenciando, em ritmo crescente, paupérrimas condições laborais que se aliam aos terríveis efeitos característicos das indústrias em causa. Com efeito, e na linha de pensamento de Ulrich Beck, em muitas culturas extraeuropeias a globalização equipara-se a uma «norte-americanização» cujas

2 U. BECK, La sociedad del riesgo. Hacia una nueva modernidad [tradução castelhana de Jorge Navarro, Daniel Jiménez e Rosa Borrás da edição original alemã de 1986], Barcelona, Paidós, 1998, p. 47. 
transformações económicas e sociais «llevan ya hoy (y aún más en el futuro) a tanta miseria e ruina que deja en la sombra incluso la "proletarización" (Karl Marx) de Europa en el siglo XIX»³.

Esta (cada vez mais intolerável) situação mundial que vai alinhavando o fado do ser humano, tem vindo a ser relacionada - um tanto ou quanto pós-modernamente, diga-se - com um paradigma subjetivista dominante da modernidade ancorado na prevalência de uma ratio calculatrix que, neste contexto, vai sendo hostilizada por diversos sectores do pensamento contemporâneo. Boaventura Sousa Santos começa por analisar este paradigma, enquadrando-o, desde logo, num arquétipo de racionalidade que se terá iniciado com a revolução científica ocorrida no século XVI, no domínio das ciências naturais, e que se terá estendido, já mais tarde no século XIX, às ciências sociais então emergentes. O sociólogo de Coimbra caracteriza-o então como um «modelo global (isto é, ocidental) de racionalidade científica», de pendor «totalitário», que não reconhece nem considera quaisquer «formas de conhecimento» que se não pautem, desde logo, «pelos seus princípios epistemológicos e pelas suas regras metodológicas» ${ }^{4}$. Neste sentido, constitui-se como um paradigma de completa rutura face aos precedentes, desenvolvendo-se «com crescente definição», no que ao plano das ciências naturais tange (isto é, plano cognitivo da razão teórica), fundamentalmente «na teoria heliocêntrica do movimento dos planetas de Copérnico, nas leis de Kepler sobre as órbitas dos planetas, nas leis de Galileu sobre a queda dos corpos»e, ainda, na «grande síntese da ordem cósmica de Newton», bem como, agora no domínio das ciências sociais ou humanas (isto é, domínio ético da razão prática), «na consciência filosófica que lhe conferem Bacon e Descartes» ${ }^{5}$. Na Idade Moderna, sublinha Jürgen Habermas, as mais relevantes dimensões do mundo da vida - seja a dimensão da religião, da política, da sociedade, seja a da ciência, da moral ou da artetransformaram-se «em personificações do princípio da subjectividade» ${ }^{6}$. A sua estrutura «é apreendida enquanto tal na filosofia, a saber, como subjetividade abstrata no cogito, ergo sum de Descartes e na figura da consciên-

${ }^{3}$ U. BeCK, Poder y contrapoder en la era global [tradução castelhana de R. S. Carbó da edição original alemã de 2002], Barcelona, Paidós, 2004, p. 106.

${ }^{4}$ Cfr. B. S. SANTOS, A crítica da razão indolente: contra o desperdício da experiência [Para um novo senso comum. A ciência, o direito e a política na transição paradigmática], vol. I, 2.. ${ }^{a}$ ed., Porto, Edições Afrontamento, 2002, p. 58.

5 Ibid.

${ }^{6}$ J. Habermas, O Discurso Filosófico da Modernidade [tradução portuguesa de Luiz Sérgio Repa e Rodnei Nascimento da edição original alemã de 1985], São Paulo, Martins Fontes, 2002, pp. 27-28. 
cia de si absoluta em Kant» ${ }^{7}$. A razão moderna emoldura-se, assim —como realça, desta feita, Anselmo de Borges—, no contexto da secularização e da «metafísica da subjectividade», ganhando, por conseguinte, contornos de fisionomia pragmática na medida em que o saber deixa de ser contemplativo para procurar «a maximização da utilidade através do domínio sobre a natureza» ${ }^{8}$. Passa então a denotar-se uma «total separação entre a natureza e o ser humano» ${ }^{9}$, vale por dizer, um «dualismo da res cogitans e da res extensa» que, «unilateralizando a razão, não só perdeu o corpo, mas também o laço de familiaridade com a natureza», transformada doravante «em mero objecto e instrumento, reservatório de energias ao serviço de uma subjectividade omnipotente» ${ }^{10}$. A subjectividade revela-se um princípio unilateral ${ }^{11}$, desembocando, portanto, e na lógica de um racionalismo moderno de fisionomia utilitarista, numa razão que se vai desvendando «tecno-instrumental coisificadora, orientada essencialmente pelo interesse de domínio» ${ }^{12}$ do ser humano sobre a natureza, sintomaticamente expressa na scientia est propter potentiam de Francis Bacon. Já Leonel Franco, também numa perspetiva de cariz filosófico-teológico, exprobrava a razão moderna —nomeadamente a de Kant, mas não só- ${ }^{13}$ enquanto glorificadora da «autonomia absoluta» do homem e da sua consequente «indepen-

7 Ibid., p. 28.

8 A. DE Borges, «O crime económico na perspectiva filosófico-teológica», RPCC, 10 (2000), p. 14.

9 B. S. SAnTos, A crítica da razão indolente..., op. cit., p. 59.

${ }^{10}$ A. DE Borges, «O crime económico na perspectiva...», op. cit., p. 14. A ideia, tipicamente cartesiana, de dupla natureza do homem, simultaneamente corpo e alma, encontra-se também no cerne do pensamento de Pascal: «o homem é o mais prodigioso objecto da natureza, pois não pode conceber o que é corpo e ainda menos o que é espírito, e menos que tudo como pode um corpo estar unido a um espírito. Aqui reside o auge das suas dificuldades e, todavia, trata-se do seu próprio ser» [apud A. Touraine, Crítica da Modernidade (tradução portuguesa de Fátima Gaspar e Carlos Gaspar da edição original francesa de 1992), Lisboa, Instituto Piaget, 1994, p. 63].

${ }^{11}$ Assim, J. Habermas, O Discurso Filosófico da Modernidade..., op. cit., p. 30.

12 A. DE BorGES, «O crime económico na perspectiva...», op. cit., p. 14.

${ }^{13}$ No sentido de uma perspetiva religiosa crítica da filosofia racional setecentista no seu conjunto, refere, por exemplo, o Autor: «o racionalista do século XVIII renuncia à luz da fé, submete aos limites da própria razão individual todo o cognoscível e recusa a plenitude da vida que lhe oferece o Evangelho. Dificilmente poderia exagerar-se a gravidade da situação criada por estas atitudes. A seguir os mentores dos novos tempos, a civilização ocidental romperia com a tradição religiosa de todo o seu passado e entraria a combater, explícita ou implicitamente, os valores espirituais que lhe deram origem, energia e vida. $\mathrm{O}$ homem novo que se prepara nas revoltas do século XVIII já não quer ser cristão, volta as costas à luz que lhe vem do Verbo da Vida e pretende nortear a sua actividade moral e organizar as estruturas sociais da Cidade com os recursos escassos de uma filosofia empobrecedora e estéril» (cfr. L. Franco, A Crise do Mundo Moderno, Lisboa, Pro Domo, 1945, p. 147-148). 
dência radical», arvorando-o em «senhor absoluto» que «dita as leis a si e ao universo que lhe volteia ao redor como em torno do seu centro natural de gravidade» ${ }^{14}$. A crítica é, assim, dirigida a uma pretensiosa magnitude universal da razão humana moderna —abrangendo tanto a sua dimensão teórico-cognitiva, quanto a sua extensão ético-prática- que instiga a um arrebatado predomínio humano sobre a natureza. Mas não se pense que nesta predominância humana sobre a natureza se esgota o conteúdo da razão moderna. $\mathrm{Na}$ esteira de Enrique Dussel, Anselmo de Borges alude, outrossim, a uma razão de teor «imperialista e eurocêntrica» que, assentando no «princípio da subjectividade», se reporta a acontecimentos históricos fundamentais anteriores à Reforma, ao Século das Luzes e à Revolução Francesa, quais sejam, os Descobrimentos e as conquistas ${ }^{15}$. Significa isto, ainda na linha de pensamento de Enrique Dussel, que o «ego conquiro de 1492» se afigura «decisivo para a constituição da subjectividade moderna» tão afamadamente enunciada, como vimos, no cartesiano «ego cogito no século XVII» ${ }^{16}$. A razão moderna não se limita, assim, ao puro domínio da natureza, surgindo ainda como «anuladora» do «outro», que é encarado na perspetiva de uma «diferença ineliminável, e eurocêntrica», como, de resto, se pode ler nas Vorlesungen über dir Philosophie der Weltgeschichte, de Hegel» ${ }^{17}$. Esta razão moderna configura-se, enfim, como «instrumental», predadora, a tal ratio calculatrix que se apresenta «quase omnipotente no domínio dos meios», mas não deixa de revelar uma «extrema penúria» no reino «dos fins», conduzindo, fatalmente, a uma «crise de valores» e, por conseguinte, a uma espécie de «deserto de sentido» ${ }^{18}$. Depara-se-nos, então, «o mundo do interesse e da individualidade a propósito do qual Schopenhauer» afirma «que, esteticamente, é uma taberna repleta de bêbedos, intelectualmente, um asilo de alienados, e moralmente, um covil de salteadores» ${ }^{19}$. Trata-se, enfim, do mundo da razão próprio de uma conspeção humana que se baseia na «subjectividade omnipotente» na qual predomina a «lógica do domínio» -isto é, a «lógica dos meios sem fins (Zweckrationalität, segundo Max Weber)»-, abrindo, inevitavelmente, o caminho para uma «sociedade cibernética e burocratizada» ${ }^{20}$.

${ }^{14}$ Ibid., p. 146.

${ }^{15}$ Cfr. A. De Borges, «O crime económico na perspectiva...», op. cit., pp. 15-16.

${ }_{16}$ Ibid., p. 16.

${ }_{17}$ Ibid.

${ }_{18}$ Ibid., pp. 23-24.

19 A. Touraine, Crítica da Modernidade..., op. cit., p. 131.

20 A. DE Borges, «O crime económico na perspectiva...», op. cit., pp. 14-15. 
Não admira, assim, que o paradigma da modernidade coincida com o modo de produção capitalista. Repare-se que o projeto sociocultural da modernidade se constituiu entre o século XVI e o século XVIII e que esse momento «coincide com a emergência do capitalismo enquanto modo de produção dominante nos países da Europa que integraram a primeira grande onda de industrialização» ${ }^{21}$. Mais uma vez nos socorremos da analogia histórica de Ulrich Beck para afirmar que, tal como na época da Revolução Industrial, a razão instrumental terá contribuído para o surgimento do liberalismo capitalista que se veio a difundir ao longo dos últimos séculos, também agora, no período da revolução tecnológica, a razão (tecno) instrumental tem fomentado um crescente neoliberalismo mundial e um exasperado capitalismo global. O fundamento primeiro será basicamente o mesmo: o «homo oeconomicus, dominado pela sede da posse crescente de bens, tomou o predomínio» ${ }^{22}$. As condições que propiciaram um tal estado de coisas terão começado — já o vimos- com os ideais liberais iluministas que vieram a desaguar na Revolução Francesa, representando um triunfo da burguesia sobre a aristocracia. Contemporaneamente é comum chamar-se a atenção para o facto de o elenco dos direitos humanos universais provenientes da ideologia iluminista e proclamados durante a Revolução Francesa se enquadrarem numa estrutura jurídica e política acentuadamente formal que perspetiva o ser humano como ente abstrato separado das suas emoções e das suas condições materiais de existência. Nesta visão das coisas lança-se uma forte crítica sobre o liberalismo iluminista na sua dimensão económica para o acusar de se constituir como instrumento de dominação dos burgueses —e, um pouco mais tarde, dos capitalistasque manipulam conceções filosóficas e políticas para adequar os seres humanos aos seus projetos. É, mais uma vez, a crítica à razão instrumental, coisificadora, interesseira, que cria conceitos filosóficos aparentemente puros e universais para subjugar as classes mais desfavorecidas.

Não será, todavia, sensato estabelecer uma pura relação simplista e linear entre o paradigma da modernidade e o capitalismo global hoje predominante $^{23}$. Neste particular, refere Boaventura Sousa Santos, estamos

${ }^{21}$ B. S. Santos, Pela Mão de Alice. O Social e o Político na Pós-Modernidade, 7.. a ed., Porto, Edições Afrontamento, p. 72.

22 A. DE BORGES, «O crime económico na perspectiva...», op. cit., p. 18.

${ }^{23}$ Para uma análise de cariz fundamentalmente sociológico sobre esta relação entre o paradigma da modernidade e o capitalismo económico, de onde se infere, desde logo, de que se não trata, efetivamente, de uma relação simplista e linear, veja-se A. TOURAINE, Crítica da Modernidade..., op. cit., pp. 38 e ss. 
perante «dois processos históricos diferentes e autónomos» ${ }^{24}$. Não olvidemos, desde logo, que o «paradigma sociocultural da modernidade surgiu entre o século XVI e os finais do século XVII, antes de o capitalismo industrial se ter tornado dominante nos atuais países centrais. A partir daí prossegue o Autor-, os dois processos convergiram e entrecruzaram-se, mas, apesar disso, as condições e a dinâmica de desenvolvimento de cada um mantiveram-se separadas e relativamente autónomas. A modernidade não pressupunha o capitalismo como modo de produção próprio. $\mathrm{Na}$ verdade, concebido enquanto modo de produção, o socialismo marxista é também, tal como o capitalismo, parte constitutiva da modernidade. Por outro lado - conclui Boaventura Sousa Santos-, o capitalismo, longe de pressupor as premissas socioculturais da modernidade para se desenvolver, coexistiu e até progrediu em condições que, na perspetiva do paradigma da modernidade, seriam sem dúvida consideradas pré-modernas ou mesmo anti-modernas» ${ }^{25}$. Mesmo a própria religião, não o ignoremos, terá tido a sua influência no desenvolvimento do capitalismo. Aqui destaca-se, inevitavelmente, a ética protestante puritana de raiz calvinista que se enquadra, segundo Max Weber, no espírito capitalista assente no racionalismo formal do cálculo custo/benefício e na ausência de constrangimentos morais a esse cálculo e possível acumulação de benefícios ${ }^{26}$. Também o protestantismo terá dado, pois, o seu contributo para a criação de «um ethos favorável ao capitalismo» ${ }^{27}$.

${ }_{24}$ B. S. SAnTos, $A$ crítica da razão indolente..., op. cit., p. 46.

${ }^{25}$ Ibid., pp. 46-47.

${ }^{26}$ Sobre esta matéria e para uma análise das muito interessantes diferenças de atitude entre católicos e protestantes face aos contextos da vida económica burguesa e capitalista, partindo de uma «panorâmica da estatística profissional de um país pluriconfessional» como era - em finais do século XIX - (e ainda é) a Alemanha, veja-se M. WeBER, A Ética Protestante e o Espírito do Capitalismo [tradução portuguesa de Ana Falcão Bastos e Luís Leitão da edição original alemã, s.d.], 5.. ${ }^{a}$ ed., Lisboa, Presença, 2001, pp. 27 e ss.

27 A. Touraine, Crítica da Modernidade..., op. cit., p. 40. Ainda que para Alain Touraine não passasse disso mesmo, uma mera contribuição. Porém, talvez, não decisiva. Até porque, como refere Touraine, ninguém «ignora que o capitalismo se desenvolveu em primeiro lugar nos países católicos, a Itália e a Flandres»; ao que acrescenta «que os países calvinistas mais rigoristas» nem «conheceram qualquer desenvolvimento económico digno de registo, com a Escócia calvinista a permanecer, durante muito tempo, em atraso em relação à Inglaterra anglicana, com o prolongado subdesenvolvimento dos países do Norte e com Amesterdão à frente do mundo capitalista por ação dos Arminianos ou partidários da Grande Exposição, bastante menos rigoristas do que os calvinistas de Genebra, cidade que no século XVI não conheceu, nem um crescimento económico brilhante nem uma atividade universitária digna de nota (a universidade de Genebra só se tornaria um centro de produção intelectual com a chegada dos cartesianos franceses no século seguinte». Por outro lado, insiste ainda Touraine, «no século XVII, na Grã-Bretanha e nos Estados Unidos em formação, de que Franklin é 
Seja como for, de forma mais ou menos direta, mais ou menos linear, e ainda que se trate de duas realidades autónomas, a verdade é que a moderna razão instrumental vem sendo relacionada com o espírito capitalista. E não sem alguma razão, diga-se. Anselmo de Borges — numa ótica um pouco diversa, talvez, da perspetiva de Boaventura Sousa Santos supra enunciada - refere-se mesmo ao espírito do capitalismo como «filho da razão instrumental na sua versão sócio-económica» ${ }^{28}$. E bem vistas as coisas, afinal, a própria ética do protestantismo (mais ou menos) puritano atrás mencionada engloba, em si, essa mesma razão instrumental enquadrável no paradigma da modernidade. Com efeito, Max Weber destaca, neste particular, algumas máximas de Benjamin Franklin em que se patenteiam as asserções morais de cunho marcadamente utilitário ${ }^{29}$, a partir das quais conclui, sintomaticamente, que uma virtude como a honestidade, por exemplo, «é útil, dado que traz crédito» ${ }^{30}$. E não só, o mesmo se passa, $v . g$., «com a pontualidade, a aplicação ao trabalho e a frugalidade, e por isso são virtudes» ${ }^{31}$. Trata-se, portanto, de uma lógica que não andará longe de um qualquer aforismo assente na ideia de que, através de desígnios divinos, «a virtude compensa», conjugando-se, assim, na perfei-

figura emblemática, a presença do calvinismo atenuou-se e o rigorismo deu lugar a um utilitarismo bastante secularizado». Arremata, então, o Autor francês, que se torna mesmo «difícil explicar o desenvolvimento do capitalismo através da influência do protestantismo mais puritano». E, referindo-se a Max Weber, de forma conclusiva: «aquilo que Weber procura compreender é, antes, um tipo particular e extremo de actividade económica: não o comerciante ou o industrial modernos, mas o capitalista propriamente dito, aquele que está inteiramente submerso na actividade económica e cuja capacidade de investimento depende da sua poupança pessoal, que não é atraído nem pelas especulações nem pelo luxo e que usa os bens do mundo como se os não usasse, segundo a fórmula de São Paulo» (cfr. A. Touraine, Crítica da Modernidade..., op. cit., p. 39).

${ }_{28}$ A. DE Borges, «O crime económico na perspectiva...», op. cit., p. 18.

29 A título de exemplo: «Lembra-te que - como diz o ditado-um homem de boas contas é senhor da bolsa alheia. Quem for conhecido por pagar as suas contas pontualmente pode a todo o momento pedir emprestado todo o dinheiro que os amigos possam dispensar. Isso pode ser de grande utilidade. A par do trabalho árduo e da frugalidade, nada contribui tanto para que um jovem vença na vida como a pontualidade e a rectidão em todos os seus negócios. Por isso, não conserves o dinheiro que te foi emprestado nem mais uma hora para além do prazo a que te comprometeste, para que o ressentimento do teu amigo não faça que ele te feche a bolsa para sempre. Um homem não pode negligenciar que as mais pequenas acções têm influência sobre o seu crédito. Se o teu credor ouvir as pancadas do teu martelo às cinco horas da manhã ou às oito da noite, ficará descansado durante seis meses; mas, se te vir à mesa do bilhar ou ouvir a tua voz na taberna quando devias estar a trabalhar, então irá reclamar-te o pagamento na manhã seguinte e exigir o seu dinheiro antes que o tenhas à tua disposição» (cfr. M. WeBER, A Ética Protestante e o Espírito..., op. cit., p. 36).

${ }^{30}$ Ibid., p. 38.

31 Ibid. 
ção a ética protestante e o espírito do capitalismo dentro de um moralismo calculista $^{32}$. E, através da razão instrumental e do seu raciocínio calculista, não deixa de ser obviamente verdade que, desde o início da evolução do capitalismo burguês moderno até aos dias de hoje, o homo oeconomicus tem vindo a servir-se calculistamente dos meios ao seu alcance -incluindo meios científicos e, mais recentemente, tecnológicos- para atingir a maximização do lucro e a consequente acumulação de riqueza. Compreende-se, assim, que se tenha vindo a convergir, progressivamente, para uma sociedade de cariz exasperadamente economicista, competitivo e consumista e que, constantemente, a tenham vindo a denominar de capitalista e neoliberal. Ao observar este modelo de sociedade que vai marcando a contemporaneidade, Anselmo de Borges realça o facto de o valor da pessoa nele inserido se não mostrar já «pelo que é, mas pelo que tem», evidenciando a circunstância de as «novas catedrais» parecerem ser agora «os hipermercados» e concluindo que a prova maior da existência também parecer ser «o hedonismo consumista: consumo, logo existo» ${ }^{33}$. Em conformidade, a própria identidade individual parece depender, em muito, dos bens que são consumidos. «To be or not to be myself» é a dúvida existencial que parece poder ser solucionada, como ressalta Jean Baudrillard, através dos bens de consumo que consigam satisfazer os gostos e os desejos da própria personalidade ${ }^{34}$. Numa tão consumista sociedade,

${ }^{32}$ Conjugação que vai implicar, no entanto - e ao contrário do que se poderia pensar- conforme sublinha Max Weber, que o espírito do capitalismo acabe por resultar do summum bonum da ética protestante e não de meros «floreados em torno de máximas puramente egocêntricas» que mais não seriam do que aquilo a que os alemães se habituaram a «considerar como "hipocrisia" nas virtudes do americanismo». Neste sentido, concretiza o sociólogo alemão: «O ganho do dinheiro, e de cada vez mais dinheiro, com a mais estrita abstenção de todos os prazeres simples, tão completamente despido de todas as perspectivas eudemonistas ou mesmo hedonistas, é de tal modo considerado um objectivo em si que em comparação com a "felicidade" ou o "proveito" do indivíduo parece algo de completamente transcendente e puramente irracional. O ganho é considerado como objectivo da vida do homem, e já não como meio de satisfazer as suas necessidades materiais. Esta inversão dos factos "naturais", se assim lhe quisermos chamar, sem sentido para uma sensibilidade simples, é manifestamente um leitmotiv do capitalismo, que se mantém alheio aos homens que não são movidos por ele. Mas, simultaneamente, ela encerra uma série de sentimentos que têm muito a ver com certas concepções religiosas. Com efeito, ao colocar-se a questão de saber por que deve "o homem fazer dinheiro", responde Benjamin Franklin [...], na sua autobiografia, com uma citação da Bíblia que, como ele diz, o pai, personagem rigorosamente calvinista, sempre lhe incutiu na juventude: "se vires um homem activo na sua profissão, ele tem a dignidade dos reis”» (ibid., pp. 38-39).

33 A. DE BORGES, «O crime económico na perspectiva...», op. cit., p. 19.

34 Jean Braudillard concretiza esta definição de personalidade através de bens de consumo relatando dois textos exemplificativos, o primeiro extraído do Le Monde, que aqui 
a competitividade economicista assume, obviamente, desmesuradas proporções. O estatuto social, as características da personalidade individual ou a admiração pelo modus vivendi de cada um dependem, fundamentalmente, do sucesso económico que se consegue obter. Daí que o próprio Anselmo de Borges, numa visão pessimista desta sociedade actual assente no que chama de «darwinismo social» a fazer lembrar o «estado de guerra» de Hobbes-, encare como desafio terminante da atualidade a urgência daquilo a que chama a «superação» da «razão moderna» «no sentido hegeliano do termo Aufhebung», isto é, «afirmada, negada, superada (suprassumida)» ${ }^{35}$. Isto implica, por conseguinte que, no contexto de um certo Zeitgeist não liberto de algum cariz pós-moderno, se imponha uma profunda reflexão ética sobre a própria conceção do homem do mundo e da vida que permita superar a razão moderna, tal como esta tem vindo a apresentar-se nos últimos tempos. E não deixará certamente de ter alguma pertinência pensar que um extremado racionalismo - assente, desde logo, na axiomática convicção de que o homem iluminado é portador de verdades universais e irrefutáveis-, porventura dominante em alguns dos sectores sociais e mundiais mais poderosos, tenha vindo a suscitar alguma carência espiritual no domínio da reflexão ética, resvalando-se para um modo de encarar a realidade que nos envolve através de uma razão que se revela, destarte, marcadamente tecno-instrumental e exasperadamente calculista.

reproduzimos: «Não há mulher, por mais exigente que seja, que não consiga satisfazer os gostos e os desejos da própria personalidade com um Mercedes-Benz! Desde a cor do couro, o guarnecimento e a cor da carroçaria até aos tampões das rodas e às inúmeras comodidades que os equipamentos estandardizados ou preferenciais oferecem», o segundo de um pequeno hebdomadário feminino: «Ter encontrado a própria personalidade e saber afirmá-la é descobrir o prazer da autenticidade pessoal. Muitas vezes, basta bem pouco. Busquei durante longo tempo e apercebi-me de que um pequeno tom claro nos cabelos era o bastante para criar a perfeita harmonia com a cor do rosto e dos olhos. A cor loira encontrei-a na gama do "shampoo" corante "Récital" [...] Com o dourado de "Récital", de matiz muito natural, não mudei: mais do que nunca sou eu mesma. Estes exemplos apontam para duas mulheres de estatutos sociais completamente diferentes, mas — como aponta Jean Braudillardo esquema do valor "pessoal" é o mesmo para ambas e para todos nós que abrimos caminho na selva "personalizada" da mercadoria "preferencial", buscando desesperadamente o fundo de tez que revelará a naturalidade do nosso rosto, o truque que ilustrará a nossa idiossincrasia profunda, a diferença que nos fará ser nós mesmos» [cfr. J. BAUdRILlard, A Sociedade de Consumo (tradução portuguesa de Artur Morão da edição original francesa, s.d.), Lisboa, Edições 70, 2010, p. 99].

35 A. DE BORGES, «O crime económico na perspectiva...», op. cit., p. 21. 


\section{POPPER E A FALIBILIDADE DA RAZÃO (TEÓRICA E PRÁTICA)}

Antes, porém, de entrarmos no domínio da reflexão ética, devemos começar por ter, desde logo, a consciência de que nem a própria razão (pura) teórica, a das ciências ditas exatas, se pode arrogar, afinal, absolutamente universal e imutável, como se - numa perspetiva científica assinaladamente positivista - o mundo não passasse de um fluir constante de fenómenos mecanicistas e determinados. Nesta dimensão epistemológica da razão, Karl Popper assume uma importância decisiva ao refutar categoricamente o determinismo científico das ciências naturais baseado no raciocínio indutivo ${ }^{36}$. Em conformidade, o ser humano deverá ter, segundo Popper, a noção dos seus limites e, por conseguinte, a perceção de que a sua razão cognitiva não esgotará, decerto, uma realidade altamente complexa. Com efeito, e ainda que a realidade «possa possuir aspetos estruturais que são simples num ou noutro sentido, a simplicidade das [...] teorias» humanas — que são isso mesmo, humanas— «não implica a simplicidade do mundo» ${ }^{37}$. Torna-se, assim, compreensível que mesmo neste domínio epistemológico exista uma constante substituição de paradigmas e que os próprios cientistas tenham tomado consciência da dimensão hermenêutica das ciências da natureza ${ }^{38}$. Mas não se pense que esta ideia de substituição de paradigmas implique o total afastamento dos dados científicos anteriores, vale por dizer, que implique um total ceticismo científico ou a uma visão aniquiladora da ciência ${ }^{39}$. Destarte, não deverá seguramente implicar, como bem nota Faria Costa, que se abandone, por exemplo,

36 Veja-se K. PopPen, O Universo Aberto: pós-escrito à lógica da descoberta científica [tradução portuguesa de Nuno Ferreira da Fonseca da edição original alemã de 1983], vol. II, Lisboa, Publicações Dom Quixote, 1992, nomeadamente pp. 57 e ss.

${ }^{37}$ Ibid., p. 59.

${ }^{38}$ Neste sentido, A. DE Borges, «O crime económico na perspectiva...», op. cit., p. 25.

39 Karl Popper, de resto, abomina, justamente, como ele próprio afirmou num passado relativamente recente (1988), «a actual moda intelectual que tenta denegrir a ciência», acrescentando que, ao invés, admira «grandemente os resultados maravilhosos obtidos actualmente por biólogos e bioquímicos e que, através da medicina, têm sido úteis a muitos pacientes em todo este mundo maravilhoso». Isto, obviamente, dentro da lógica da constante substituição de paradigmas, pois Karl Popper auto-define-se «como um amante da ciência que tem a maior admiração pelos resultados maravilhosos e frequentemente verdadeiros da ciência, sem no entanto acreditar que eles sejam certos». E concretizando: «os resultados da ciência continuam a ser hipóteses que podem ter sido bem testadas, mas não provadas: quer dizer, não foi demonstrado que sejam verdadeiras. Claro que podem ser verdadeiras. Mas mesmo que não o sejam, são hipóteses óptimas, abrindo caminho a outras ainda melho- 
«para tantas e tantas coisas, o rigor fulgurante da física newtoniana ${ }^{40}$. $\mathrm{Na}$ verdade, a mencionada ideia de substituição de paradigmas apenas nos indica que a realidade física se não esgota nem nos dados empíricos cientificamente comprovados nem nas teorias científicas que desses dados indutivamente decorrem. Trata-se, portanto, de teorias que devem apenas ser encaradas, nas próprias palavras de Karl Popper, como «redes concebidas por nós para apanhar o mundo» ${ }^{41}$. Elas mostram-se inegavelmente úteis, ainda que devamos ter a consciência de que não esgotam a realidade. Temos sempre a possibilidade de conseguir melhorá-las, é certo, se fizermos «redes cada vez mais bem adaptadas para apanhar o nosso peixe, o mundo real», mas sempre com a noção de que «nunca serão instrumentos perfeitos para esse fim». Deveras, elas «são redes racionais de nossa autoria e não deveriam ser tomadas erradamente, por uma representação completa do mundo real em todos os seus aspetos. Nem mesmo se forem altamente bem-sucedidas; nem mesmo se parecerem dar excelentes aproximações da realidade» ${ }^{42}$. Neste modo de pensar a ciência teórico-cognitiva, Karl Popper desemboca, então, no seu conhecido critério essencial para a caracterização das teorias científicas, qual seja, o critério da falsidade — «reconhecidamente, a ciência padece da falibilidade humana, tal como qualquer outro empreendimento humano» ${ }^{43}$ baseado na premissa de que as leis provenientes das teorias científicas não podem ser absolutamente confirmadas, mas podem ser falseadas. Elas serão, assim, válidas enquanto não for demonstrada a sua falsidade, o que leva Popper a recomendar aos cientistas que procurem provar a falsidade das teorias consi-

res» [cfr. K. Popper, Um Mundo de Propensões (tradução portuguesa de Teresa Barreiros e Rui Feijó da edição original alemã, s.d.), Lisboa, Fragmentos, 1991, p. 17].

${ }^{40}$ J. F. DE F. Costa, «A linha (algumas reflexões sobre a responsabilidade em um tempo de "ética" e de "bio-ética")», Linhas de Direito Penal e de Filosofia: alguns cruzamentos reflexivos, Coimbra, Coimbra Editora, 2005, p. 41.

${ }^{41}$ K. Popper, O Universo Aberto..., op. cit., p. 58.

${ }^{42}$ Popper concretiza com um exemplo: «se testámos um enunciado como "todos os cães têm cauda" e ele resistiu aos nossos testes, então talvez todos os cães (ou gatos) tenham cauda, ou, pelo menos, aproximadamente todos. Mas seria um erro concluir a partir do facto de se ter descoberto que uma tal frase sujeito-predicado universalizada resulta bastante bem para descrever o mundo, ou até do facto de ela ser verdadeira, que o mundo tem uma estrutura sujeito-predicado, ou que é composto de substâncias com determinadas propriedades». E mais adiante: «se dizemos "todos os cães têm cauda", estamos de facto a afirmar algo acerca de todos os cães. Isto é claro porque podemos ter de retirar o enunciado se descobrirmos uma raça de cães sem cauda (análoga à raça Manx de gatos sem cauda). Assim, a universalidade é algo que as nossas teorias afirmam e que expomos a testes» (ibid., pp. 58-59 e 60).

${ }^{43}$ K. Popper, Um Mundo de Propensões..., op. cit., p. 17. 
deradas válidas, permitindo que essa validade (conhecimento) exista conjeturalmente ${ }^{44}$, na medida em que assenta em específicos pressupostos e abrange, tão-somente, uma parte da realidade. «As nossas teorias, as nossas hipóteses» - sintetiza Popper - «são as nossas tentativas arrojadas. Reconhecidamente, a maior parte delas acaba por se revelar errónea; sob o impacto dos nossos testes, pode revelar-se a sua falsidade. As teorias que nós não conseguimos refutar com os testes mais duros, presumimos serem verdadeiras. E, na verdade, elas podem ser verdadeiras; mas novos testes podem vir a provar que são falsas» ${ }^{45}$.

Este despertar de um sono profundamente universal e imutável, de raiz newtoniana, que, no plano epistemológico da razão humana, dominou o pensamento filosófico durante o Iluminismo, foi, como se sabe, acompanhado do desentorpecimento de um sossego ético-filosófico que assentava nos mesmos contornos racionais de pendor totalizante. Em conformidade, também os princípios (dogmas?) emergentes da razão (ainda que pura) prática, não deverão escapar — a fortiori (ou, pelo menos, a pari) — à fatalidade da imperfeição humana que envolve a constante renovação de paradigmas, o que parece reforçar a supra aludida necessidade de uma profunda reflexão ético-filosófica no domínio das Ciências Humanas que se revele superadora da razão tecno-instrumental como demanda Anselmo de Borges. E numa determinada forma de encarar o pensamento filosófico, esta necessidade não deixa mesmo de apresentar contornos de arrimo pós-moderno ao apoiar-se, inevitavelmente, num desconstrucionismo das grandes narrativas racionalistas que, desmistificando a capa das verdades universais e imutáveis, julgam colocar a nu os reais objetivos das classes dominantes assentes, fundamentalmente, na imposição de ideologias de natureza político-filosófica que lhes sejam interesseiramente mais favoráveis. Seja como for, e independentemente dos (não mais pretensiosos do que perigosos) juízos de valor infligidos aos reais (?) propósitos dessas grandes narrativas, parece-nos efetivamente inegável que as conceções integralmente (absolutamente) racionalistas de alguns sectores do Iluminismo (nomeadamente) de raiz germânica acabaram por confluir — de forma mais ou menos linear, fruto de interpretações de maior ou menor honestidade intelectual — em construções político-filosóficas de carácter absolutizante, particularmente as de estirpe hegeliana e marxista. Tal confluência será tributária, segundo nos parece, de uma enfatuada e

$$
\begin{aligned}
& { }^{44} \text { Ibid. } \\
& { }^{45} \text { Ibid., p. } 18 .
\end{aligned}
$$


arrogante tentação de reduzir todo o real à compreensão racional humana e que conduziu a perspetivas filosófico-políticas fundadas num dialéctico sentido da História (Historicismo) - quer pela via do desenvolvimento do espírito do mundo (o Zeitgeist de Hegel), quer pela vereda de um materialismo dialéctico transformador do mundo (Marx) — ${ }^{46}$ que esqueceu, conforme lembra Karl Popper, a lição socrática dos limites humanos da ignorância ${ }^{47}$.

${ }^{46}$ Sobre esta visão redutora da realidade submetida a um todo racional conducente a um dialético sentido da História (Historicismo) baseado no desenvolvimento do espírito do mundo (Hegel), ou a um materialismo dialético que visa transformar o mundo (Marx), veja-se S. Neiman, O Mal no Pensamento Moderno. Uma História Alternativa da Filosofia [tradução portuguesa de Vítor Matos da edição original inglesa de 2002], 1.. ed., Lisboa, Gradiva, 2005, pp. 103 e ss. Também Isaiah Berlin, a ilustrar, de forma simples e sagaz, o Historicismo de Hegel, afirma que, na visão hegeliana, o crescimento e o desenvolvimento humano da História apenas pode ser explicado «através da dialética, nomeadamente por um qualquer processo evolutivo, por um dinamismo de algum tipo». E concretizando: «Essa colisão de tese e antítese, essa perpétua oposição de forças, é que é responsável pelo progresso. Essas forças não são meramente pensamentos nos cérebros dos indivíduos: "encarnam-se" em instituições, em igrejas, em constituições políticas, possivelmente em grandes empreendimentos humanos, nas migrações dos povos, em revoluções, por exemplo, ou em vastos desenvolvimentos intelectuais, em que a tese e a antítese no seu estado de tensão interior mútua e contínua se aproximam de um clímax. Dá-se a explosão e a síntese é gerada, como uma espécie de Fénix, das cinzas da tese e da antítese». Explicitando, ainda: por «vezes esse desenvolvimento ocorre sob a forma de atividades nacionais: por vezes há heróis individuais que personificam esses avanços - Alexandre, César, Napoleão-. É certo que esses indivíduos destruíram muito; é certo que provocaram um sofrimento enorme. Isso é a consequência inevitável de qualquer tipo de progresso. Sem fricção não há progresso». Concluindo, mais adiante: «quando estudamos História, acredita Hegel, alcançamos um nível suficientemente racional, ascendemos a um determinado estádio de conhecimento em que começamos a compreender que os acontecimentos históricos não apenas ocorreram de determinado modo, como tinham de ocorrer assim, inevitavelmente; não no sentido da causalidade mecânica com que a física trabalha mas, mais exatamente, por exemplo, no sentido em que seguimos os passos de um raciocínio matemático para o qual existem regras rigorosas; ou talvez mesmo os de uma sinfonia, para a qual não existem regras tão fixas, mas em que podemos afirmar que cada fragmento sucessivo é, por assim dizer, inevitável ou, como Hegel poderia dizer, um "sucessor racional" do fragmento anterior, pelo que dizemos que o trecho anterior "não faz sentido" a menos que o trecho subsequente esteja lá para o completar, do modo como o padrão de um tapete pode ser traçado» [cfr. I. BERLIN, Rousseau e outros cinco inimigos da liberdade (tradução portuguesa de Tiago Araújo da edição original inglesa de 2002), Lisboa, Gradiva, 2005, pp. 114 a 116].

${ }^{47}$ Cfr. K. Popper y K. Lorenz, O Futuro Está Aberto [tradução portuguesa de Teresa Curvelo da edição original alemã de 1983], 2.. ${ }^{a}$ ed., Lisboa, Fragmentos, 1990, p. 61. 


\section{A NECESSIDADE, NÃO OBSTANTE, DE UM PARADIGMA DE BASE RACIONAL}

Mas se é verdade que alguns sectores oriundos do racionalismo iluminista terão levando longe de mais um certo ideal de «Império da Razão», portador de um exacerbado espírito absoluto e, enquanto tal, redutor da realidade, é também nosso entendimento que todo o diagnóstico de traços catastróficos da realidade moderna não deve, por outro lado, implicar o resvalar para desvairados desconstrucionismos pós-modernos que, sob ferozes ataques ao «racionalismo tirânico» e ao homem demasiadamente teórico, abstrato ou religioso, se tornam suscetíveis de nos reconduzir para um confrangedor niilismo, de travo nietzschiano. Deveras, esta muito em voga ligação do pós-modernismo ao pensamento de Nietzsche -a que, de resto, já aludimos- opera, fundamentalmente, na negação da moral de dimensão metafísica — seja esta de pendor racional-abstrato ao jeito socrático-platónico, seja de cariz espiritual-religioso, de inspiração cristã — ${ }^{48}$, situando-se, pois, num desértico niilismo que acaba, tragicamente, por impregnar o ser humano de angustiantes dúvidas existenciais pela completa ausência de valores. E se é sob o fundamental pretexto de evitar a opressão do homem pelo homem que não nos opomos, bem pelo contrário, à crítica de uma qualquer sorte de racionalismo dialético e totalizante, mal se compreenderia, então, o encaminhamento pelo axiologicamente vazio rumo do niilismo. Efetivamente, enveredar por um ideal assente na completa ausência de valores que, por isso mesmo, conduz à sua própria superação por chamamento de uma qualquer espécie de «super-homem» (Übermensch) — qual (anti)Messias dos novos tempos surgido não se sabe muito bem de que montanhas e dominado por

${ }^{48}$ A negação da metafísica por Nietzsche é um dos pontos fulcrais da sua filosofia crítica em relação à cultura dominante no século XIX que teria sido marcada pela influência racionalista e decadente de Sócrates ao invadir a tragédia grega após esta ter atingido o equilíbrio da forma e da paixão simbolizadas por Apolo e Dionísio [veja-se F. NIETzsche, O Nascimento da Tragédia ou Mundo Grego e Pessimismo (tradução portuguesa de Teresa Cadete da edição original alemã de 1872), Lisboa, Relógio D'Água Editores, 1977]_, aparecendo, invariavelmente, ao longo da sua obra de forma clara e direta. Atente-se, $v$. g., nas palavras de Zaratustra: «Eu vos conjuro, ó meus irmãos, mantende-vos fieis à terra e não acrediteis naqueles que vos falam de esperanças supra terrenas. Cientes disso ou não, são envenenadores. São desprezadores da vida, moribundos, intoxicados, de quem a terra está cansada: que pereçam, pois!» [cfr. F. NIETZSCHE, Assim Falava Zaratustra. Livro para todos e para ninguém (tradução portuguesa de Carlos Grifo Babo da edição original alemã, s.d.), 4.. ${ }^{\text {e }}$ ed., Lisboa, Presença, 1978, p. 12]. 
uma assanhada sede de poder (ou de viver)—, acaba (mal, bem, grosseira ou justamente interpretado) por legitimar, similarmente, como é de resto consabido, formas de opressão insuportavelmente esmagadoras da livre autodeterminação humana e, portanto, desconformes à inalienável dignidade do ser humano. Aliás, toda a lógica desconstrucionista aplicada às grandes narrativas racionalistas enquadrável, como vimos, em uma nova forma de pensar — catalogada como «pós-moderna»— centrada na crítica à modernidade, não se furta, também ela, a diversas críticas assentes, fundamentalmente, na circunstância comum de o seu conteúdo se apresentar demasiado vago, impreciso ou mesmo vazio. Com efeito, não deixará realmente de ser verdade que ao falar-se em «pós-modernidade» se aponte um modo de pensar e encarar a época histórica atual que, bem vistas as coisas, se vai afirmando sobretudo pela via negativa, isto é, se vai impondo e difundindo, basicamente, através de uma primária atitude de oposição à modernidade sem grandes preocupações em se fundar num razoável modelo de sociedade alternativo. Seria, aliás, muito interessante imaginar um tal modelo alternativo que rejeitasse, por exemplo, o racionalismo económico; seria, decerto, pouco menos do que entrar numa dimensão surrealista. Francis Fukuyama faz precisamente este exercício num excerto que não resistimos a transcrever: «enquanto indivíduos e pequenas comunidades» «regressariam à natureza», «trocando os seus empregos como banqueiros ou construtores civis por uma vida à beira de um lago nos Andirondacks, uma rejeição da tecnologia por toda a sociedade significaria a total desindustrialização de uma nação da Europa, América ou Japão e a sua efetiva transformação num empobrecido país do Terceiro Mundo. Talvez a poluição atmosférica e os resíduos tóxicos fossem em menor quantidade, mas diminuiria também a qualidade da medicina e das comunicações, assim como o controlo da natalidade, o que restringiria a liberdade sexual. Em lugar de libertar o homem do ciclo dos novos desejos, a vida da maior parte das pessoas assemelhar-se-ia à de um pobre camponês amarrado à terra num ciclo infernal de trabalho árduo. É certo que muitos países sobreviveram durante gerações a uma agricultura de subsistência tendo, sem dúvida, os seus habitantes obtido um nível considerável de felicidade; improvável é que eles pudessem viver assim depois de terem experimentado o consumismo de uma sociedade tecnológica e, sobretudo, que pudessem ser persuadidos, como sociedade, a trocar uma pela outra. Além disso, se outros países não se desindustrializassem, os 
habitantes dos que o fizessem teriam contra si um padrão de comparação constante» ${ }^{49}$.

Parece-nos, de facto, uma utopia irresponsável tentar proclamar a erupção de uma nova época que se arvora em superadora da Idade da Razão e de todos os seus desastres e pragas. Acresce que, do mesmo jeito, o discurso pós-moderno não assume o lugar que ocupa. Nem, aliás, pretende fazê-lo. Nas palavras de Jürgen Habermas, «dialéctica negativa, genealogia e desconstrução esquivam-se de maneira análoga àquelas categorias segundo as quais o saber moderno, não por acaso se diferenciou e que hoje constituem a base de nossa compreensão dos textos» ${ }^{50}$. O discurso pós-moderno de crítica radical da razão não pode, assim, ser classificado univocamente «nem como filosofia ou ciência, nem como teoria moral e jurídica, nem como literatura e arte», do mesmo passo que resiste «a um retorno às formas de pensamento religioso, sejam dogmáticas ou heréticas» ${ }^{51}$. Existe, pois, enfim, «uma incongruência» entre as «teorias» pós-modernas «que levantam pretensões de validade apenas para desmenti-las e o modo da sua institucionalização no domínio científico» ${ }^{52}$. Daí que estas críticas (pós-modernas) à modernidade não consigam deixar de soar a «profetismo barato ${ }^{53}$ e desabem em ocos «arrebatamentos irracionalistas» ${ }^{54}$, traduzidos, fundamentalmente, no anúncio da «doença» (Horkheimer), agonia e consequente morte da razão ${ }^{55}$. Paulo de Sousa Mendes afirma ser este, precisamente, o espírito da época pós-moderna; espírito que, bem vistas as coisas, se não consubstancia, afinal, em mais do que — nas suas tão corrosivas quão elucidativas palavras - inçar «esborralhados púlpitos de desatinados apóstatas que ostentam as respetivas exúvias a cada passo do arrazoado conceptual». E ao dirigir-se à própria terminologia com que se cataloga esta época, Sousa Mendes não deixa de complementar ainda não sem algum motejo— que toda esta «facúndia advém», afinal, «da facilidade com que são capazes de juntar o inexpressivo prefixo pós ao tema

${ }^{49}$ F. FukuYama, O Fim da História e o Último Homem [tradução portuguesa de Maria Goes da edição original inglesa de 1992], 2.. ${ }^{\text {a }}$ ed., Lisboa, Gradiva, 1999, pp. 99-100.

50 J. HABERMas, O Discurso Filosófico da Modernidade..., op. cit., p. 467.

${ }^{51}$ Ibid.

52 Ibid.

53 É a expressão de D. Bermejo, Posmodernidad: pluralidad y transversalidad, Barcelona, Antrophos, 2005, p. 126.

54 P. de S. MendEs, Vale a pena o direito penal do ambiente?, Lisboa, AAFDL, 2000, p. 43.

$55 \mathrm{Ou}$ «eclipse da razão», aproveitando o título da famosa obra de Horkheimer, publicada em 1955, em que, pela primeira vez, aparece, de forma filosófica, uma crítica da razão instrumental. 
do sermão. Não se entende» — arremata— «a razão para tantos ditirambos à custa desta entronização do «pós», mas é um facto que há grande vozearia em prol da pós-modernidade. São mais as vozes do que as nozes. A verdade é que» — conclui, então, o penalista de Lisboa- «o projecto da modernidade não acabou»; realmente — parafraseando Beck— «ainda agora começou uma nova forma de modernidade» ${ }^{56}$. Nesta linha, também Diego Bermejo, por exemplo, contesta a própria legitimidade do termo «pós-modernidade», atendendo a que as conotações do prefixo utilizado implicam a alusão a uma nova época histórica claramente diferente e superadora da anterior, a da modernidade. Em rigor, todavia, ajuíza identicamente o Autor espanhol, a modernidade continua vigente e a sua despedida nem parece ser desejável. Basta que se tenha em conta, por exemplo, a modernização social ou a modernidade cultural. Quem, realmente, poderá contestar - questiona retoricamente Bermejo um pouco na linha de Francis Fukuyama- com pretensão de validade os benefícios do bem-estar social obtidos pelo processo de modernização tecno-científica ou renunciar às vantagens da cultura, da democracia e da liberdade? ${ }^{57}$.

Já Fredric Jameson, uns anos antes, chamava, aliás, a atenção para o facto de as várias correntes pós-modernas, oriundas das mais diversas áreas de manifestação humana, não passarem, na sua maioria, de formas de contraposição selectiva face aos cânones da modernidade, opondo-se, por conseguinte, ao seu predomínio fosse nas Universidades, nos museus, no circuito das galerias de arte ou nas fundações ${ }^{58}$. Ora, em tais circunstâncias, avaliava Jameson, dificilmente se poderá falar em «pós-modernidade» como algo coerente e afirmativo, pois a sua unidade —se é que tem alguma- não se fundava «em si mesma, mas em relação ao próprio modernismo contra o qual ela investe» ${ }^{59}$.

${ }^{56}$ Cfr. P. de S. Mendes, Vale a pena o direito penal..., op. cit., p. 43.

57 Cfr. D. Bermejo, Posmodernidad: pluralidad..., op. cit., p. 126.

58 Referindo-se aos diferentes estilos modernos, acrescenta o Autor, concretizando: «Estes estilos, que no passado foram agressivos e subversivos -o Expressionismo Abstracto, a grande poesia de Pound, Eliot e Wallace Stevens, O International Style (Le Corbusier, Frank Lloyd Wright, Mies), Stravinsky, Joyce, Proust e Thomas Mann—, que escandalizaram e chocaram nossos avós, são agora, para a geração que entrou em cena nos anos 60 , precisamente o sistema e o inimigo: mortos, constrangedores, consagrados, são monumentos reificados que precisam ser destruídos para que algo novo venha a surgir. Isto que dizer que serão tantas as formas de pós-modernismo quantas foram as formas pós-modernas, uma vez que as primeiras não passam, pelo menos de início, de reacções específicas e locais contra os seus modelos» [cfr. F. JAMESON, «Pós-modernidade e sociedade de consumo» (tradução portuguesa de Vinicius Dantas da versão original inglesa), Novos estudos, 12 (1985), p. 17].

59 Ibid. 
À falta de um pensamento coeso e positivo, acrescem diversas consequências perniciosas do pós-modernismo, como seja a de um exacerbado relativismo - muito característico, aliás- que leva à incerteza, à obscuridade e à confusão, gerando, consequente, como menciona Silva Sánchez, uma crescente desorientação pessoal vertida no que Smart denominou «vertigem da relatividade» ${ }^{60}$. O Papa João Paulo II, de resto, assinalou-o criticamente. Começando por constatar a ambiguidade, desde logo, do próprio termo, João Paulo II invoca algumas das correntes de pensamento que fazem referência à pós-modernidade para aludir ao seu traço definidor comum assente na ideia de que «o tempo das certezas teria», de facto, «passado» e de que «o homem deveria finalmente aprender a viver num horizonte de ausência total de sentido, sob o signo do provisório e do efémero». Muito interessante, curiosa e sagaz a ligação que é feita, então, neste seguimento, pelo Sumo Pontífice, entre o niilismo próprio do pós-modernismo e um exasperado historicismo que vê «na história o avanço vitorioso da razão, fonte de felicidade e de liberdade». Assim, uma subjugação de cariz absolutizante ao totalitarismo da razão tecnocientífica é também uma postura filosófica produzida (ou melhor, proporcionada) pelo pós-modernismo - como tantas outras, aliás, no contexto daquela «vertigem da relatividade»— radicada na «ilusão de que, graças às conquistas científicas e técnicas, o homem, como se fosse um demiurgo, pode chegar, por si mesmo, a garantir o domínio total do seu destino» ${ }^{61}$.

Com o que fica dito, pretendemos sobretudo significar que, do nosso ponto de vista, o tempo histórico atual se não deverá constituir como o momento adequado para a referida agonia e consequente morte da razão. Em sintonia com Figueiredo Dias, pensamos tratar-se do momento, isso sim, em que se impõe uma introspeção reflexiva do paradigma racional herdado da Ilustração, para que se possa assumir, cerca de três séculos passados, muitos dos seus equívocos e limites ${ }^{62}$ sem que isso coloque em causa esse mesmo paradigma que, em nosso entendimento, deverá continuar a prevalecer como postulado basilar da filosofia ética que funda os alicerces do Estado de Direito plural e, enquanto tal, laico.

${ }^{60}$ Cfr. J. M. Silva SÁnchez, La expansión del Derecho penal. Aspectos de la política criminal en las sociedades postindustriales, Madrid, Edisofer, 2011, p. 22.

${ }^{61}$ João Paulo II, A Fé e a Razão (carta encíclica Fides et Ratio), 4.. ${ }^{a}$ ed., Lisboa, Edições Paulinas, 2003, capítulo VII, nota de margem 91.

${ }^{62}$ J. de F. Dias, Direito Penal - Parte Geral. Questões Fundamentais. A Doutrina Geral

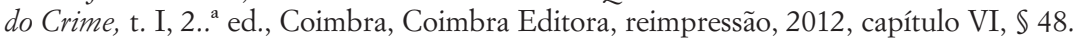


Com efeito, e sem com isso deslizarmos para um exacerbado racionalismo de carácter absolutizante e reducionista, o consenso racional e generalizado dos cidadãos - Figueiredo Dias chega mesmo a referir-se a um «novo contrato social»- ${ }^{63}$ construído sobre a liberdade bumana ${ }^{64}$ sobrevirá, ainda, como o melhor instrumento definidor dos valores fundamentais a respeitar numa sociedade que se pretenda democrática. Em causa está, como ponto de partida, não o esqueçamos, a própria sobrevivência da espécie humana que se expressa, afinal, no mais importante (numa perspetiva humana) dos Dez Mandamentos, «não matarás!». Aqui se contém, destarte, e nas palavras de Karl Popper, «quase toda a ética», na medida em que - e agora com referência a Schopenhauer- esta se constitui, basicamente, como «uma ampliação deste importantíssimo mandamento» ${ }^{65}$. Neste desígnio de sobrevivência da espécie humana tanto podemos encontrar fundamentos de carácter racional transcendental, quanto de sinal religioso ou mesmo de puro instinto humano (e animal). Mas, o que já parece ser insofismável é que, neste enquadramento, a ratio calculatrix se apresenta com uma funcionalidade decisiva na medida da premência de um raciocínio calculador determinante para a definição dos valores cujo respeito se afigura instrumentalmente necessário para a salvaguarda da preservação da espécie humana. Aí, a tolerância, e o respeito pela diversidade não podem, obviamente, ser descartados. E num ciclo histórico propenso ao contacto multicultural onde a revolução tecnológica se vai desenvolvendo nas múltiplas teias interligadas da comunidade global —abrangendo, fatalmente, orlas de terrorismo - confluindo no tópico da sociedade de risco, mais premente se torna a consciencialização da necessidade de acatamento desses valores, de sorte a poder cultivar-se um generalizado pacifismo e a consequente salvaguarda da liberdade e vida humanas. Karl Popper invoca Voltaire —a quem chama «pai do Iluminismo»— para fundamentar, em sintonia com o ponto de vista socrático — expresso no «só sei que nada sei e quase nem isso»—, a necessidade de respeito pela tolerância, quan-

${ }^{63}$ Ibid.

${ }^{64}$ Neste sentido, Figueiredo Dias, na esteira de Baptista Machado e fugindo à ideia do racionalismo absoluto próprio de um Historicismo dialético reducionista, ressalta a ideia de «liberdade do homem que se realiza no mundo e que o obriga à participação na humanidade histórica; e de que é elemento essencial uma atitude de "abertura" e de "participação", de ser-com e de ser-para-os-outros, através da qual não recuse o seu contributo pessoal para a humanização do mundo e da história» (ibid.).

${ }^{65}$ Cfr. K. Popper, Sociedade Aberta, Universo Aberto (entrevista conduzida por Franz Kreuzer em 1979) [tradução portuguesa de Maria Helena Rodrigues Carvalho da edição original alemã de 1982], Lisboa, 1995, p. 96. 
to mais não seja, desde logo, por uma questão de probidade intelectual. E, concretizando, afirma: «Voltaire bem sabe que há fanáticos absolutamente convictos»; para, em seguida, perguntar: mas «será a sua convicção absolutamente honesta? Ter-se-ão analisado honestamente a si próprios, às suas convicções e aos fundamentos destas? E não é a autoanálise crítica uma parte de toda a probidade intelectual? E não é o fanatismo, muitas vezes, uma tentativa de abafarmos a nossa própria e inconfessada descrença que reprimimos e da qual, por isso, só estamos parcialmente conscientes?» ${ }^{66}$. Karl Popper pretende, pois, evidenciar a falibilidade das convicções absolutas, o que implica a necessidade de tolerância pelas convicções oriundas das mais diversas mundividências culturais. À semelhança do que acontece no domínio cognitivo da razão teórica, também os princípios de conduta provenientes da razão prática são falíveis e, portanto, questionáveis. E se assim é, impõe-se então que esses princípios se busquem nos grandes espaços de consenso comunitários resultantes de contínuos processos discursivos em que imperem as regras do diálogo racional, despreconceituoso e isento de coerção, ao estilo habermasiano. Deste modo, poder-se-ão obter, com pretensão de validade, os valores fundamentais de uma «pragmática universal» —ainda ao jeito de Habermas— ${ }^{67}$, isto é, aqueles valores que, não obstante serem substituíveis — como sucede com as leis da razão teórica-, se mostrem aptos, calculistamente, a propiciar a salvaguarda de outros valores que, nos dias de hoje - e (porque não?), também, eventualmente, no passado ou no futuro-, devem - perdoe-se-nos o arrimo kantiano (e habermasiano) — assumir carácter universal —ainda que não absoluto no seu conteúdo- ${ }^{68}$, quais sejam a vida, a paz e a dignidade bumana ${ }^{69}$. Estes parecem constituir-se, destarte, como os valores cuja

${ }^{66}$ Cfr. Popper, Karl, Sociedade Aberta, Universo Aberto (entrevista conduzida por Franz Kreuzer em 1979) [tradução portuguesa de Maria Helena Rodrigues Carvalho da edição original alemã de 1982], Lisboa, Publicações Dom Quixote, 1995, p. 97.

${ }^{67}$ Habermas utiliza o conceito «pragmática universal», atribuindo-lhe a função de «identificar e reconstruir condições universais de possível compreensão mútua (Verständigung)». Abrange, pois, os «pressupostos gerais de comunicação» ou, numa linguagem mais habermesiana, os «pressupostos gerais de acção comunicativa» [cfr. J. HABERMAS, Racionalidade e Comunicação (tradução portuguesa de Paulo Rodrigues da versão original alemã de 1976), Lisboa, Biblioteca de Filosofia Contem, 2002, p. 9]. Neste contexto, Habermas desenvolve o tema, tentando estabelecer esses pressupostos, para que, em conformidade, se possa delinear uma linguagem universal, transversal aos diversos jogos de linguagem (veja-se J. Habermas, Racionalidade e Comunicação..., op. cit., pp. 9 e ss).

${ }_{68}$ Até porque, como se sabe, em um Estado de Direito que se pretenda materialmente liberal e democrático deve sempre resistir-se à tentação de absolutizar valores ou princípios.

${ }^{69}$ Apesar do arrimo kantiano (pela sua natureza necessária e universal), estes valores não são necessariamente encontrados na consciência racional da humanidade, podendo 
salvaguarda se mostra necessária e premente para que se cumpra o desígnio «não matarás!».

É certo que a paz é instrumental da vida e que a dignidade humana obriga a que o mandamento «não matarás!» seja interpretado à luz da proteção de uma vida humana digna. Como é certo também que muitos outros valores tidos como consensualmente essenciais - o que, aliás, se pode retirar, por exemplo, da própria Declaração Universal dos Direitos do Homemsão, também eles, instrumentais desse mandamento fundamental, a saber, v. g., a tolerância de que falava Popper (sem ela dificilmente haverá paz), a liberdade, a solidariedade (fraternidade?) ou a igualdade (necessárias, desde logo, para a preservação de uma vida minimamente digna), numa evolução (muito próxima) dos valores proclamados logo após a Revolução Francesa. Note-se, pois, a manifesta importância da razão instrumental no que tange à tarefa de selecionar (através do diálogo racional) os valores cuja proteção garanta a preservação da espécie humana. Valores estes que serão, sem dúvida, faliveis e, portanto, substituiveis, mas que só deverão ser tidos como falsos e carentes de substituição se (e/ou quando) se vislumbrarem outros valores preferíveis, e portanto mais eficazes, tendo em vista a mencionada preservação da espécie humana. Mas, por ora, enquanto perdurarem estes valores, tanto mais deverão assumir a categoria de universais, quanto mais nos encontrarmos numa sociedade de risco onde a evolução tecnológica os coloca cada vez mais em perigo, nomeadamente através da guerra, do terrorismo e dos atentados ambientais. Se assim não for, isto é, se estes valores não assumirem, deveras, o estatuto de fundamentais para toda a Humanidade e a sua salvaguarda não for efetiva, será exatamente a mesma Humanidade que desaparecerá do planeta. E se já realçamos, invocando Ulrich Beck, o efeito boomerang a propósito, basicamente, dos atentados ambientais, devemos também ter consciência de que cada vez menos se pode encarar lucidamente a guerra —incluindo o terrorismocomo uma tentativa de vitória sobre o «outro», sobre o inimigo. A evolução tecnológica dos meios bélicos também aqui faz sentir o efeito boomerang aludido e no despoletar de uma guerra torna-se difícil distinguir entre vencedores e vencidos, pois esta configura-se, cada vez mais, como uma derrota de toda a Humanidade. A vida, a paz e a dignidade bumana devem, assim, constituir-se como os valores universais e superiores do homem de

sê-lo no instinto humano (e animal, de resto) de sobrevivência. O sentido que aqui pretendemos dar à razão será, portanto, essencialmente instrumental, calculador, apto à salvaguarda dos valores que permitam essa sobrevivencia. 
todas as latitudes se pretendermos que nessas mesmas latitudes continue a existir o homem.

Pode assim compreender-se que também Jürgen Habermas não enverede pelos caminhos da «pós-modernidade», acreditando que o projeto da modernidade ainda se não tenha concretizado, até porque, não obstante alguns «excessos racionalistas» do Iluminismo, se trata do projeto que, através da ação comunicativa e do discurso racional intersubjetivo dos cidadãos, melhor poderá, até prova em contrário, fundamentar a salvaguarda daqueles valores ${ }^{70}$. Isto não significa o refutar de uma (pós-moderna?) atitude relativista no que às diversas mundividências culturais e aos diferentes jogos de linguagem concerne. Lembremos, desde logo, com Popper $^{71}$, que esse relativismo se encontra na base da ideia de tolerância e de respeito pelo «outro» e que, enquanto tal, se mostra necessário para a salvaguarda da paz. Sem, portanto, descurarmos o relativismo e o pensamento contextual —que são irrenunciáveis porque potenciam o respeito à diferença cultural e tornam possível a sempre saudável mudança de perspetiva ou compreensão dos valores alheios-, não devemos também renunciar a um ponto de partida universalista ${ }^{72}$ que garanta valores como a paz entre os homens. Realmente, para que a paz possa, de facto, prevalecer, parece-nos inevitável que o relativismo encontre os seus limites num mínimo denominador comum racional que envolva todo o universo da Humanidade, desaguando no universalismo contextual de Ulrich Beck ${ }^{73}$. Nem o relativismo se pode, afinal, absolutizar. $\mathrm{O}$ «relativismo dogmático» ou, se quisermos, o «contextualismo totalizador» (Ulrich Beck) ${ }^{74}$ além de paradoxal encerra em si os gérmenes da sua própria destruição. «Cuando todo es relativo, esto significa (considerado en una situación de caricatura), que el conquistador tiene su ponto de vista y el conquistado suyo propio; por su parte, el caricaturista observador y su público tienen también sus propios puntos de vista. Entre todos ellos se abren abismos más ou menos insuperables» ${ }^{75}$. Devemos, pois, enfim, ter consciência, conforme sustenta Silva Sánchez, que se tudo é igualmente verdadeiro, então acaba por se

\footnotetext{
${ }^{70}$ Veja-se, por exemplo, J. Habermas, O Discurso Filosófico da Modernidade..., op. cit., pp. 467 e ss.

${ }^{71}$ Ut supra ponto 3

72 Assim, U. BECK, ¿Qué es la globalización? Falacias del globalismo, respuestas a la globalización, Barcelona, Paidós, 2008, pp. 120-121.

${ }_{73}$ Ibid., p. 120.

${ }^{74}$ Ibid., p. 121.

75 Ibid.
} 
impor a força como o argumento mais poderoso ${ }^{76}$. Assim, se aspirarmos a um fundamento legitimador do poder político que, por um lado, não tenha um cariz religioso, moralista ou (tanto quanto possível) interesseiro, e que, por outro lado, seja o garante da protecção jurídica dos valores em causa, então não poderemos prescindir de um paradigma de base racional que viabilize a elaboração de uma estratégia calculadora que efectivamente proteja esses valores, o mesmo é dizer, uma estratégia que se revele útil à(s) sociedade(s) humana(s), no sentido elementar de uma vivência social minimamente digna, livre, pacífica e plural. Contudo, para que este conceito de utilidade social não tenha aquele cariz interesseiro mencionado, impõe-se que façamos, antes de mais, o chamamento de John Stuart Mill, pois é basicamente no sentido que lhe é conferido pelo filósofo e economista inglês que o empregamos.

\section{A LIÇÃO DE STUART MILL, A (POSSÍVEL) UTILIDADE SOCIAL DA RAZÃO CALCULADORA E O NEOCONTRATUALISMO DE RAWLS}

O próprio Stuart Mill se preocupou em refutar aquelas críticas à teoria da utilidade que, atingindo sobretudo os epicuristas, assentavam na perspectiva de que, se esta teoria buscava a felicidade através da busca do prazer e da ausência de dor, então tratava-se de uma teoria moral abjecta e mesquinha «digna apenas de porcos, aos quais os seguidores de Epicuro foram, desde muito cedo, comparados com desprezo» ${ }^{77}$. Ora, já os próprios epicuristas sempre foram respondendo que são os seus críticos quem representa a natureza humana de uma forma lamentavelmente degradante, na medida em que aquelas críticas implicam a suposição de que os seres humanos são incapazes de prazeres para além daqueles de que os porcos são capazes. Mas, evidentemente, os seres humanos possuem faculdades mais elevadas de que os apetites animais e, quando ganham consciência delas, nada encaram como felicidade que não inclua a satisfação das mesmas $^{78}$. E apesar de Stuart Mill se distanciar dos próprios epicuristas na definição dos conceitos de prazer e de felicidade ${ }^{79}$, a verdade é que se

76 Veja-se J. M. Silva SÁnCHEZ, La expansión del Derecho penal..., op. cit., p. 23.

77 J. S. Mill, Utilitarismo [tradução portuguesa de Azevedo Gonçalves da 4.." edição original inglesa de 1871], Lisboa, Gradiva, 2005, p. 51.

${ }_{78}$ Ibid., pp. 51-52.

79 Ibid., pp. 52-53. 
situa precisamente na linha dos epicuristas a sua célebre frase que pretende, desde logo, demarcar esses conceitos de uma visão inferior dos mesmos, qual seja, «é melhor ser um ser humano insatisfeito do que um porco satisfeito; um Sócrates insatisfeito do que um idiota satisfeito» ${ }^{80}$. Acresce, ainda, que a felicidade invocada por Stuart Mill —e cuja busca deve orientar a conduta humana - nem se resume à felicidade na própria pessoa individual, mas à felicidade no todo ${ }^{81}$. Vale isto basicamente por dizer que o chamamento de Stuart Mill serve, acima de tudo, para evocar um conceito de utilidade social que, ancorando-se numa razão útil, se constitui, antes de mais, como «a última instância de apelo de todas as questões éticas» ${ }^{82}$. Assim, esta razão utilitária —e, enquanto tal, calculadora — não deve ser confundida com a perspectiva de uma razão instrumental puramente egoística - e, nesse sentido, interesseira-, absolutamente condicionada ao mero bic et nunc. Deve, antes, ser percebida como uma razão calculadora que demanda a salvaguarda de interesses duradouros da própria Humanidade entrecruzados na busca da felicidade e do bem comum. Trata-se, portanto, «de uma concepção de utilidade no sentido mais lato, assente sobre os interesses permanentes do homem enquanto ser em devir» ${ }^{83}$.

A referência a Stuart Mill pretende, pois, significar, desde logo, que, realmente, a ratio calculatrix utilitária se pode revelar deveras profícua para a felicidade do ser humano e, portanto, não deve ser encarada - no que poderíamos qualificar de visão pós-moderna radical—, pura e simplesmente, como um mal em si mesmo. Até porque, como razão técnica que é, a razão calculadora configura-se, em si, despida de quaisquer conteúdos valorativos, o mesmo é dizer, assume-se como axiologicamente neutra. É uma razão instrumental que tanto pode servir o bem quanto o mal. Tenhamos em mente, por um lado, que é esta razão calculadora que está na base do ideal contratualista de Hobbes, Locke ou Rousseau, tão importante para a evolução político-jurídica da Humanidade e que, justamente

${ }^{80}$ Ibid., p. 54.

${ }^{81}$ Chega mesmo a firmar o filósofo inglês: «o utilitarismo exige que o agente seja tão estritamente imparcial entre a sua própria felicidade e a dos outros como um espectador desinteressado e benevolente. Na regra de ouro de Jesus de Nazaré vemos o espírito completo da ética da utilidade. Fazer aos outros o que queremos que nos façam a nós, e amar ao próximo como a si mesmo, constituem a perfeição ideal da moralidade utilitarista» (ibid., pp. 63-64).

82 Apud M. SANDEL, O Liberalismo e os Limites da Justiça [tradução portuguesa de Carlos Pacheco do Amaral da edição original inglesa de 1998], Lisboa, Fundação Calouste Gulbenkian, 2005, p. 24.

83 [Itálico nosso] Apud ibid. 
em Hobbes, permitiu, na sua génese, invocar um fundamento, o contrato social, que contrariasse o trágico destino do bomo hominis lupus. Mas é também, por outro lado, como de resto nos lembra Anselmo de Borges, esta mesma razão calculadora que, em múltiplas circunstâncias, nos tem conduzido, outrossim, a muitos desastres e pragas ${ }^{84}$. Esta ambivalência é perfeitamente compreensível, na medida em que a ratio calculatrix se constrói, como elucida Kant, através de «proposições [...] técnicas» ${ }^{85}$ consubstanciadas no que o filósofo de Könisberg chama de imperativos hipotéticos, isto é, imperativos que —nas próprias palavras de Kant- «determinam [...] as condições de causalidade do ser racional, enquanto causa eficiente, simplesmente em relação ao efeito e à capacidade para o produzir», pelo que mais não envolvem do que «simples prescrições de dexteridade (Geschicklichkeit) ${ }^{86}$. Trata-se, portanto, de uma dimensão da razão — a dimensão calculadora (axiologicamente neutra)— que, em si, se não pode arvorar em mentora de uma ética de conduta, pois, como refere o próprio Kant, os imperativos hipotéticos — por contraposição aos imperativos categóricos—, sendo «condicionados, isto é», não determinando «a vontade simplesmente como vontade, mas apenas em vista de um efeito desejado [...], são sem dúvida preceitos práticos, mas não leis» ${ }^{87}$. Esta essência da razão técnica é também, de resto, colocada em evidência por Jürgen Habermas na sua crítica a Herbert Marcuse a propósito do conceito de racionalidade introduzido por Max Weber que definia «a forma de actividade económica capitalista, do tráfego social regido pelo direito privado burguês e da dominação burocrática» ${ }^{8}$. Para Marcuse, como denota Habermas, aquilo que Max Weber chama de «racionalidade» traduz uma forma de dominação política oculta. E é a esta forma de dominação política oculta do homem sobre o homem e sobre a natureza que se vem chamando (pós-modernamente) razão técnica, sendo precisamente este o sentido —ainda na exposição de Habermas- que Marcuse assume quando pretende afirmar que a razão técnica avocou um carácter ideológico. No desenvolvimento desta ideia, Marcuse denota mesmo que a razão técnica é, ela própria, ideologia. E esta encarnação abrange não «só a sua aplica-

${ }^{84}$ Cfr. A. Borges, «O crime económico na perspectiva...», op. cit., pp. 12-13.

85 I. Kant, Crítica da Razão Prática [tradução portuguesa de Artur Morão da edição original alemã de 1788], Lisboa, Edições 70, 1989, Primeira Parte, livro I, $\$ 3$, nota 1.

${ }^{86}$ Ibid., $\mathbb{S} 1$.

${ }^{87}$ Ibid.

${ }^{88}$ J. Habermas, Técnica e Ciência como «Ideologia» [tradução portuguesa de Artur Morão da edição original alemã de 1968], Lisboa, Edições 70, 1994, p. 45. 
ção, mas já a própria técnica» que «é dominação metódica, científica, calculada e calculante (sobre a natureza e sobre o homem)». Neste sentido, explica Marcuse que «determinados fins e interesses da dominação não são outorgados à técnica apenas «posteriormente» e a partir de fora», antes se inserem «já na própria construção do aparelho técnico»; assim, «a técnica é, em cada caso, um projecto histórico-social», nele se projectando, pois, «o que uma sociedade e os interesses nela dominantes pensam fazer com os homens e com as coisas». Conclui, então, Marcuse que «um tal fim de dominação é "material" e, neste sentido, pertence à própria forma da razão técnica» ${ }^{89}$. Ora, esta é uma perspectiva, já em si, ideológica da razão que não esgota a sua essência. Com efeito, encarar a razão técnica nesta lógica de dominação oculta absoluta é, também, por sua vez, uma atitude ideológica. A própria ratio calculatrix, como foi supra aludido e como tem vindo a ser conotada pela própria modernidade, dimensiona-se para além desta lógica de dominação. Ela pode mesmo revelar-se útil para superar os efeitos nocivos de uma razão técnica enquadrada nessa conceção de absoluto domínio do homem sobre o homem e do homem sobre a natureza. Não se impõe, por conseguinte, como pretende Marcuse, que se supere a razão técnica tal como ela existe e que se procure uma nova ciência e uma nova tecnologia como um mito romântico. Uma tal atitude pressuporia uma visão redutora da razão técnica. Seria uma visão de exasperada fisionomia baconiana que abrange, certamente, uma parte da razão técnica, mas, insistimos, não a esgota.

Assim, em nosso modo de ver, o problema da contemporaneidade que nos envolve não implica propriamente a necessidade de superação (nem, muito menos, de supressão) da razão tecno-instrumental; o que está em causa neste particular é, antes, a simples tomada de consciência de que, por má utilização desta razão —afinal, a mera téchne aristotélica—, o homo hominis lupus actual pode destruir o planeta. Impõe-se, então, hoje mais do que nunca, que se estabeleçam limites ético-jurídicos à actuação humana de modo a que essa mesma razão instrumental não conduza a resultados catastróficos. A consciência ética racional da Humanidade deve acompanhar os progressos da evolução tecnológica. Não se trata, pois, de destruir a razão enquanto paradigma fundamental da modernidade, mas de utilizá-la pragmaticamente, enquadrando-a numa linha de conformidade com os valores fundamentais aludidos ${ }^{90}$ —ou, se quisermos (voltando à linguagem

${ }^{89}$ Cfr. ibid., pp. 46-47.

${ }^{90}$ Uma razão, na linguagem de Habermas, inserida num processo argumentativo que, 
aristotélica), harmonizando-a com a sábia phronesis_- E, neste particular, pensamos que o modelo mais seguro e mais neutro -isto é, menos ideológica ou religiosamente comprometido (e, neste sentido, mais sintonizado com as sociedades plurais)—, continua a ser o modelo teórico explicativo assente na ideia de contrato social, enquadrado, hoje, no horizonte teórico do neocontratualismo encabeçado por John Rawls.

Se no contratualismo clássico os indivíduos partem de um estado de natureza e, por conseguinte, são considerados como iguais — seja enquanto selvagens egoístas dotados do poder de se defrontarem entre si num completo estado de guerra à maneira hobbesiana, seja como virtuosos anarquistas ou bons selvagens providos de iguais direitos naturais, ao jeito de Locke e de Rousseau-, em John Rawls o assento tónico da sua doutrina contratualista é colocado no que designa de «posição original», situação em que os indivíduos de uma comunidade partem, outrossim, em circunstâncias de completa igualdade. Todavia, para Rawls, esta posição original não se caracteriza nem por um qualquer estado de guerra nem por uma qualquer condição cultural primitiva, situações que acabariam por comportar o risco interpretativo de induzir a concretas situações históricas reais. Trata-se, diferentemente, de uma assumida «situação inicial [...] puramente hipotética» ${ }^{91}$ na qual se encontrariam os indivíduos antes de contratarem, envolvidos, na sua totalidade, no que Rawls denomina de «véu de ignorância». Esta figura metafórica do véu de ignorância justifica-se pela circunstância de o filósofo norte-americano pretender que esses mesmos indivíduos se encontrem impedidos de conhecer as suas respetivas situações particulares, nomeadamente as de índole social e económica ${ }^{92}$. A posição original não é mais, assim, do que «o statu quo inicial adequado, o qual garante que os acordos nele alcançados são equitativos» ${ }^{93}$. O apelo é feito, pois, a uma «situação hipotética» através de uma abstração que concebe

«ao incluir a dimensão prático-moral assim como a estético-expressiva» é mais rica do que «a racionalidade com respeito a fins, moldada para a dimensão cognitivo-instrumental» (cfr. J. Habermas, O Discurso Filosófico da Modernidade..., op. cit., pp. 437-438).

${ }^{11}$ Cfr. J. Rawls, Uma Teoria da Justiça [tradução portuguesa de Carlos Pinto Correia da edição original inglesa de 1971], Lisboa, Presença, 1993, p. 40.

${ }_{92} \mathrm{O}$ objetivo de Rawls é o de que os seres racionais envoltos num véu de ignorância escolham princípios de justiça equitativa em que ninguém seja beneficiado ou prejudicado por circunstâncias particulares, tais como a posição social ou as condições económicas. E, concretizando através de um exemplo simples, afirma: «Se alguém soubesse que era rico, poderia achar racional tentar a aprovação do princípio de que são injustos os impostos que financiam as medidas de natureza social; se a mesma pessoa soubesse que era pobre, iria provavelmente impor o princípio contrário» (ibid., p. 38).

${ }_{93}$ Ibid., p. 37. 
seres racionais envoltos num «véu de ignorância»—e, enquanto tais, livres nas suas escolhas-, em busca, mediante um contrato a que se vinculam, de um conceito de justiça consensual e unânime que norteie os princípios sob os quais se torna legítimo governar a estrutura básica da sociedade.

Ao neocontratualismo de John Rawls não é certamente alheio o contexto filosófico de tradição utilitarista anglo-saxónica que, como vimos, tem em Stuart Mill um dos seus mais ilustres pensadores, mas de onde se destacam muitos outros como, por exemplo, Hutcheson e Bentham. Rawls desenvolve, com efeito, a sua doutrina nesse enquadramento filosófico, notando-se, com evidência, uma certa linha de continuidade, traçada, fundamentalmente, no meridiano de uma pragmática ratio calculatrix. Isto, sem embargo de se tratar de uma doutrina que acaba, todavia —e não sem alguma inspiração kantiana-, por marcar um fracionamento, ou até mesmo uma oposição, face a esse tradicional pensamento utilitarista de onde proveio. John Rawls, aliás, apresenta a sua doutrina contratualista precisamente como uma alternativa ao utilitarismo clássico tecendo-lhe, por conseguinte, fortes críticas. De entre essas críticas ressalta, fundamentalmente, um aspeto essencial, qual seja, o entono dado pelos utilitaristas —nomeadamente Stuart Mill (talvez, nem tanto, o seu mestre Jeremy Bentham) - ao interesse comum ou coletivo, enquadrando-se o utilitarismo na corrente de pensamento a que hoje grande parte da doutrina filosófico-política norte-americana designa de comunitarismo que, ao jeito rousseauniano, defende intransigentemente a prevalência da vontade da maioria, por contraposição ao liberalismo que preza, acima de tudo, a liberdade individual e os direitos humanos universais ${ }^{94}$. Neste enquadramento, Rawls, ao partir de uma formulação da teoria utilitarista protagonizada por Sidgwick — «a sociedade está bem ordenada e, portanto, é justa quando as suas instituições principais estão ordenadas de forma a conseguir a maior soma líquida de satisfação, obtida por adição dos resultados de todos os sujeitos que nela participam»- ${ }^{95}$, destaca o facto de o utilitarismo - tal como decorre, igualmente, de Stuart Mill- se centrar, fundamentalmente, no bem-estar colectivo, ainda que à custa, se necessário for, dos direitos individuais. Rawls começa por aceitar a ideia de que o raciocínio calculista utilitarista aparenta constituir-se como a conceção mais racional de justiça. Isto, na medida em que parte da premissa calculadora de que na pros-

\footnotetext{
${ }_{94}$ Quanto a esta matéria e em uma perspectiva que tenta, de alguma forma, harmonizar «comunitarismo» e «liberalismo», veja-se M. SANDEL, O Liberalismo e os Limites..., op. cit., pp. 9 e ss.

${ }^{9}$ Cfr. J. Rawls, Uma Teoria da Justiça..., op. cit., p. 41.
} 
secução dos seus próprios interesses cada um é livre de equilibrar os seus próprios ganhos e perdas, ou seja, é livre de impor a si próprio um sacrifício imediato para tentar obter, posteriormente, uma maior vantagem ${ }^{96}$. É, pois, perfeitamente natural, legítimo e correto que, através da razão calculadora, uma pessoa prescinda de um determinado prazer individual para que possa realizar interesses superiores que busque a mais longo prazo. Não é mais, aliás, do que o racional e clássico princípio de prudência aplicado aos comportamentos individuais. O que John Rawls critica, todavia, no utilitarismo é a aplicação deste raciocínio, por analogia, a uma comunidade que busca interesses coletivos fundados no bem-estar do grupo. É verdade — Rawls aceita-o— que uma tal analogia não deixa de se revelar coerente, na medida em que é encarada como uma extensão do princípio da escolha individual. Trata-se, afinal, do «princípio da prudência racional aplicado a uma conceção agregativa do bem-estar do grupo» ${ }^{97}$. Porém, o perigo de uma conceção desta espécie reside na possibilidade de acabar por aceitar como legítimo, correto e, mesmo, aconselhável que se sacrifiquem interesses individuais em favor do bem-estar da coletividade ou da maioria. É que, como afirma Rawls, para «a visão utilitarista de justiça não importa, a não ser indiretamente, o modo como a soma das satisfações é distribuída entre os sujeitos, da mesma forma que não importa, também salvo indiretamente, a forma como os sujeitos distribuem a sua satisfação no tempo. Em ambos os casos, a distribuição correta é aquela que produz a máxima satisfação. A sociedade deve afetar os seus meios de satisfação, sejam eles quais forem (direitos e deveres, oportunidades e privilégios e as diversas formas de riqueza), se possível de forma a atingir este máximo» ${ }^{98}$. Mesmo Stuart Mill — reconhece John Rawls— que defende o respeito e a salvaguarda de certos preceitos de senso comum sobre a justiça, em especial os que tocam a proteção de direitos e liberdades individuais, admite que os sacrifiquemos, ainda que a título excecional, se a soma dos benefícios for com isso maximizada ${ }^{99}$. Neste encadeamento, Rawls conclui então

96 Assim, ibid.

${ }^{97}$ Ibid., p. 42.

98 Ibid., p. 43.

99 John Rawls reporta-se aos dois últimos parágrafos do capítulo $\mathrm{V}$ do Utilitarianism de Stuart Mill (ibid., p. 43, nota 13). E, com efeito, Stuart Mill afirma nesses parágrafos, em jeito de conclusão face ao que foi desenvolvido no referido capítulo: «Pelo que fica dito, dá a impressão de que a justiça é um nome para certos preceitos morais que, encarados colectivamente, se situam num plano mais elevado da escala social, e são por isso de mais proeminente obrigação do que outros; embora possam ocorrer casos particulares nos quais outro dever social seja tão importante que revogue qualquer uma das máximas de justiça. Assim, 
que, no contexto do pensamento utilitarista, não há razão para que «os maiores ganhos de alguns não compensem as perdas, comparativamente menores, de outros; ou, mais importante, para que a violação da liberdade de alguns não possa ser justificada por um maior bem partilhado por muitos» ${ }^{100}$. Para John Rawls, em suma, o erro da doutrina utilitarista está em «confundir impessoalidade com imparcialidade» ${ }^{101}$.

A superação encetada por John Rawls face ao utilitarismo clássico radica, sobretudo, no recurso ao hipotético e metafórico «véu de ignorância». O filósofo liberal norte-americano sobrepõe, em conformidade, o conceito de dever, enquanto oriundo de uma ideia de justiça, face ao bem (dos utilitaristas), cuja concepção se encontra demasiadamente condicionada a contingências individuais e particulares ${ }^{102}$. O recurso ao falado «véu de ignorância» foi, assim, o mecanismo encontrado por Rawls para libertar os cidadãos das suas contingências empíricas e interesseiras no momento do contrato social, o que, afastando o seu neocontratualismo do utilitarismo clássico, o aproxima dos imperativos puros de Kant e do próprio consenso

para salvar uma vida, pode não ser apenas permissível, mas um dever, roubar, ou tomar pela força a comida ou os medicamentos necessários, ou raptar o único médico competente e forçá-lo a exercer. Em tais casos (uma vez que não chamamos justiça ao que não for uma virtude), não dizemos, habitualmente, que a justiça deve dar lugar a qualquer outro princípio moral, mas sim que o que é justo em caos normais é, em virtude desse outro princípio, injusto neste caso particular. Mediante esta útil adaptação da linguagem, o carácter da inviolabilidade atribuído à justiça é mantido, e ficamos a salvo da necessidade de defender a possibilidade de injustiças louváveis.

Penso que as considerações agora aduzidas resolvem a única verdadeira dificuldade da teoria utilitarista da moral. Foi sempre evidente que todos os casos de justiça são também casos de expediência: a diferença está no sentimento peculiar que se liga à primeira em oposição à última. Se este sentimento característico foi suficientemente tido em conta; se não há qualquer necessidade de supor que tem uma origem peculiar; se é simplesmente o sentimento natural de ressentimento, moralizado ao ser tornado co-extensivo às exigências do bem social; e se este sentimento não apenas existe, como deveria existir, em todos os tipos de casos aos quais corresponde a ideia de justiça; essa ideia deixa de surgir como um obstáculo à ética utilitarista. A justiça continua a ser o nome adequado para certas utilidades sociais que são muitíssimo mais importantes, e por isso mais absolutas e imperativas, do que quaisquer outras o são enquanto classe (embora não mais do que outras podem ser em casos particulares); e, por isso, deveriam ser, tal como o são por natureza, protegidas por um sentimento não apenas diferente em grau, mas também em género; e distinguidas do sentimento menos intenso que se liga à mera ideia de promover o prazer humano ou a conveniência, simultaneamente pela natureza mais definida das suas exigências e pelo carácter mais severo das suas sanções» (cfr. J. S. Mill, Utilitarismo..., op. cit., p. 128-129).

100 J. RaWls, Uma Teoria da Justiça..., op. cit., p. 43.

101 [Itálico nosso] Ibid., p. 158.

102 Sobre esta matéria veja-se, fundamentalmente, J. Rawls, Sobre las libertades [tradução castelhana de Jorge Vigil Rubio da edição original inglesa de 1982], Barcelona, Paidós, 1996, pp. 42 e ss. 
racional isento de coerção de Habermas. E esta libertação dos ingredientes empíricos dos cidadãos implica, necessariamente, que o acordo contratualista de Rawls seja indubitavelmente não histórico, evitando, desta feita, juízos calculadores egoísticos face às gerações futuras, aproximando-se, pois, ainda mais, do pensamento de Kant. Deveras, a ética kantiana, apresenta, como se sabe, um forte sentido da proteção da Humanidade que extravasa, em nosso entender, a finitude do ser individual ou colectivo, englobando, pois, semper et ubique, o ser vindouro. Não olvidemos, com efeito, o mandato incondicionado (imperativo categórico) proclamado como lei fundamental pelo filósofo de Könisberg que exige o domínio de uma regra tal que, com total independência do conteúdo moral do ato, pode ser convertida em lei universal de conduta ${ }^{103}$. Isto implica, necessariamente, que, tal como sucede com a filosofia rawlsiana - ainda que por caminhos diferentes-, o campo de aplicação da ética kantiana se não cinja apenas a um determinado estádio temporal da História, ao mero bic et nunc ${ }^{104}$.

\section{QUAL O FUTURO DA FILOSOFIA POLÍTICA? O LIBERALISMO ENQUANTO «FIM DA HISTÓRIA» (FUKUYAMA) OU UM (PÓS-MODERNO) REQUIEM PELO PARADIGMA ILUMINISTA? OLHAR A PÓS-MODERNIDADE É OLHAR A PRÉ-MODERNIDADE?}

Estes contornos intemporais (a-históricos) das doutrinas de Kant e Rawls conduzem-nas, pois, ao casamento com perspetivas éticas muito próprias da contemporaneidade, preocupadas fundamentalmente com a

103 «Age de tal modo que a máxima da tua vontade possa valer sempre ao mesmo tempo como princípio de uma legislação universal» (I. Kant, Crítica da Razão Prática..., op. cit., p. 42).

${ }^{104}$ Paulo de Sousa Mendes, denotando que o modelo da ética tradicional vem sendo pensado e fundamentado apenas para seres humanos contemporâneos —alicerçando-se em injunções e máximas que se alimentam do «princípio do altruísmo recíproco» (o exemplo paradigmático encontra-se na chamada regra de ouro da justiça e no sinalagma negativo entre o indivíduo e os seus semelhantes viventes que a integra: «não faças aos outros o que não gostarias que eles te fizessem a ti») —, conclui que a própria lei moral kantiana rege apenas relações entre os seres humanos viventes ( $\mathrm{cfr}$. P. de S. Mendes, Vale a pena o direito penal..., op. cit., p. 78, nota 87). Esta última asserção, porém, não merece a nossa concordância, atendendo a que o mandato incondicionado kantiano, necessário e universal, é, por definição, independente das condições a priori de tempo e de espaço, não podendo deixar de abranger, por conseguinte, o ser contemporâneo e o ser vindouro. É este o alcance, em nossa perspetiva, do imperativo categórico dirigido ao agir humano que impõe que a máxima de vontade possa valer sempre ao mesmo tempo como princípio de uma legislação universal, assumindo-se, destarte, como intemporal. 
civilização tecnológica e as inerentes potenciais implicações do modelo da sociedade de risco. Sobressai, neste particular, a ética enunciada por Hans Jonas devido à sua preocupação — mais do que pertinente— de fundamentar racionalmente a necessidade de proteção das gerações vindouras. Com este fito, e seguindo, de resto, uma metodologia de inspiração kantiana, Hans Jonas invoca um imperativo «adaptado ao novo tipo de agir humano» que se condensa em várias formulações alternativas das quais ressalta a seguinte: «age de tal forma que os efeitos da tua acção sejam compatíveis com a permanência de uma vida autenticamente humana sobre a terra» ${ }^{105}$. Será verdade, porém, que, não obstante os seus bons propósitos, este imperativo, que traduz o princípio da responsabilidade, acaba por não conseguir afinal —segundo o entendimento do próprio Autor-, sustentar-se em fundamentos puramente racionais. Realmente, se, por um lado, se harmoniza com o direito de cada um escolher para si um determinado modelo de vida que proporcione bem-estar, ainda que isso implique o custo de uma existência breve do ponto de vista individual, já se não compatibiliza, por outro lado, com o direito de toda uma geração optar por esse mesmo bem-estar se só conseguido à custa de uma previsível existência breve da coletividade humana, colocando, nessa medida, em perigo a vivência das gerações futuras. Desta feita, conclui Hans Jonas que a legitimação teórica deste seu imperativo talvez se não obtenha sem um necessário recurso a fundamentos de índole religiosa, chegando mesmo a considerá-lo um axioma sem justificação ${ }^{106}$. Pela nossa parte, parece-nos, todavia, que se coaduna com a segunda formulação do imperativo categórico de Kant ${ }^{107}$, que, acima de tudo, impõe uma não instrumentalização da Humanidade face a quaisquer desígnios exteriores, não se distinguindo, pelo próprio conceito em causa se relativa ao passado, ao presente ou ao futuro. O próprio Prinzip anderer Menschen a que a formulação kantiana conduz é necessário e universal, logo, voltamos a insistir, não condicionado pelo tempo ou espaço. Assim se pode conferir um fundamento puramente racional ao princípio da responsabilidade de Hans Jonas na medida em que se enquadra no

${ }^{105}$ Cfr. H. Jonas, Le Principe Responsabilité. Une éthique pour la civilisation technologique [tradução francesa de Jean Greish da edição original alemã de 1979], Paris, Flamarion, 2001, p. 40.

${ }_{106}$ Cfr. ibid., p. 41.

107 «Handle so, dass du die Menschbeit sowohl in deiner Person, als in der Person eines jeden andern jederzeit zugleich als Zweck, niemals bloss als Mittel brauchest» (I. KANT, Grundlegungen zur Metaphysik der Sitten, Sttutgart, Reclam, 1996, p. 79) [«Age de tal maneira que uses a humanidade, tanto na tua pessoa como na pessoa de qualquer outro, sempre e simultaneamente como fim e nunca simplesmente como meio»]. 
pensamento puro de Kant. Verdadeiramente, uma perspetiva que encare a Humanidade como fim em si não se compadece com comportamentos aptos a hipotecar a vivência das gerações futuras.

Subsistem, pois, múltiplas razões que nos levam a continuar a defender alguns valores de raiz iluminista nas suas linhas gerais fundamentais, ainda que adaptados aos tempos atuais e à abertura de espírito que os sistemas contemporâneos implicam. É que se não preconizarmos a defesa destes valores fundados num racionalismo aberto — aproveitando a lição de Karl Popper-, motivados por uma qualquer ânsia pós-moderna de superação de um passado (apenas porque é passado) — que estabelece limites (racionais) baseados, fundamentalmente, no liberalismo contratualista-, corremos o risco, não obstante a bondade das intenções (que não discutimos), de ser reconduzidos, afinal, a um passado ainda mais distante (e obscuro) e cair numa qualquer espécie de neoabsolutismo ou mesmo de neoconfessionalismo, se nos for permitido utilizar as expressões. Órfãos da razão, que futuro nos seria efetivamente reservado do ponto de vista da legitimação do poder político? Retornaríamos a um Estado Confessional? Capitularíamos ao domínio arbitrário das culturas (pretensamente) dominantes? Sacralizaríamos a demagogia dos habilidosos líderes de massas?

Em oposição ao que amiúde se insinua, ou mesmo acusa, o projecto iluminista não se caracteriza na imposição de um modelo cultural. O esforço da doutrina contratualista — nomeadamente, a de Rawls-é, ao invés, o de estabelecer princípios de justiça libertos, tanto quanto possível, de ingredientes empírico-culturais e, portanto, abertos à convivência multicultural. A doutrina (neo)contratualista apenas se limita a estabelecer o ponto de partida da legitimação do poder político e de princípios fundamentais de Justiça (enquanto equidade), não se pretendendo arvorar - muito pelo contrário- em fundamento ou motor de conceções de marca cultural, religiosa ou ideológica. Consagra, é certo, valores fundamentais, mas no contexto de um «consenso de sobreposição» alicerçado no «pluralismo razoável». Estes valores com carácter universalizante atrás enunciados, isto é, a vida, a paz, a dignidade bumana, a liberdade e a solidariedade, seriam decerto consensualizados no (neo)contratualismo de Rawls, pois os contratantes (cidadãos) envoltos no véu de ignorância nada saberiam acerca das suas condições particulares, vale por dizer, desconheceriam por completo se essas condições particulares se traduziriam ou não em situações, $v$. g., de benefício de atividades ambientalmente perigosas, de superioridade bélica ou de domínio político, pressupostos egoisticamente necessários à defesa daquelas atividades ambientalmente perigosas, à apologia da guerra 
ou ao encómio do totalitarismo. Assim, a ideia de posição original admite, logicamente, um vasto pluralismo (o pluralismo razoável), conquanto cada um não saiba se a sua própria cultura, religião ou ideologia política são as dominantes, o que conduz a grandes espaços de consenso e a uma sociedade que, necessariamente, será plural, aberta a uma ampla convivência multicultural, inter-religiosa, democrática e respeitadora dos direitos humanos individuais. E se o pós-modernismo não consegue ser um projeto coerente (ou mesmo um projeto), aqui se abarcam, afinal, as principais pretensões que se conseguem vislumbrar nesse pós-modernismo.

Os valores vida, paz, dignidade humana, liberdade e solidariedade são defendidos, mais ou menos coerentemente, por múltiplas correntes filosóficas, por diversos tipos de religiões ou por diferentes ideologias políticas. Mas para se almejar a uma sociedade justa, equitativa e plural que faça a apologia de tais valores ao serviço do ser individual, o fundamento primeiro que os sustenta deverá ser o acordo, o contrato. Existem, não o negamos, alternativas: «Lei Divina»; «Imperativos Morais»; «Autoridade do Líder (melhor ou pior dissimulada na vontade popular)». Mas se não pretendermos cair nas mencionadas situações do tipo neoabsolutista ou em uma qualquer sorte de Estado neoconfessional e almejarmos, ao invés, uma sociedade laica (ou, antes, plurirreligiosa), multicultural, plural e democrática, então, afinal, não há alternativa ${ }^{108}$. E, assim sendo, não poderá a razão ser postergada pelo paradigma da (nova?) modernidade. Tanto do ponto de vista do fundamento dos valores a salvaguardar quanto da perspetiva do instrumento dessa salvaguarda. E não se afirme que o projecto iluminista falhou ancorado no paradigma de uma ratio calculatrix predadora. É verdade que a Humanidade vive contemporaneamente num mundo de risco, mas poder-se-á também especular que, dada a natureza destrutiva que vem evidenciando ao longo dos tempos, o ser humano poderia mesmo já ter caminhado para a sua completa destruição, não fora a prevalência de certos princípios ético-jurídicos de base racional que vão contra motivando esses ímpetos autodestruidores. O problema é que, muitas das vezes, o ser humano tende a utilizar a razão instrumental de forma interesseira, egoística, apoiando-se nas suas condições particulares, ignorando valores que ele próprio defenderia se colocado na posição original. Mas isto é um pouco o bomo bominis lupus. Não é um mal da razão.

108 Assim, J. Rawls, Justiça como Eqüidade: uma reformulação [tradução portuguesa de Cláudia Berliner da edição original inglesa de 2002], São Paulo, Martins Fontes, 2003, pp. 20-21. 
É uma potencial característica da instintiva e, de certa forma, predadora natureza humana.

Com o que fica expendido, pretendemos sobretudo ressaltar que a lógica do homo oeconomicus alicerçada no método de uma ratio calculatrix competidora não deve, pura e simplesmente, ser subvertida ou derrubada. Bem pelo contrário, se, através da analogia, nos fosse permitido utilizar um lugar-comum aplicado à realidade económica, diríamos que, no limite, o capitalismo se revela (nos dias de hoje e até prova [prática] em contrário) o pior sistema económico com exceção de todos os outros. Mas para que o ser humano se não autodestrua e não ponha em causa a sua própria Humanidade enredado num puro racionalismo económico de impetuosa competitividade, deve articular essa lógica económica com postulados filosóficos fundamentais (também ele baseados na razão) que se mostrem aptos a viabilizar um precioso auxílio aos desígnios da metafórica mão invisivel invocada por Adam Smith. Neste sentido, impõe-se o respeito pelos cinco valores fundamentais a que temos vindo a fazer referência, vida, paz, dignidade bumana, liberdade e solidariedade que representam, enfim, axiomas basilares essenciais impostos pela razão humana como condição da sua própria existência, fundamentados, em nosso modo de ver, no (neo)contratualismo de Rawls que se harmoniza com o imperativo categórico de Kant e, mais recentemente, com o imperativo de Hans Jonas. São estes valores que nos poderão guiar, na linguagem de Francis Fukuyama, para o mundo pós-histórico, vale por dizer, para um mundo enquadrado num avançado estádio da História (o último?) em que o triunfo das democracias liberais se vai espalhando pelas diversas latitudes nas quais, havendo ainda Estados-nações, os «diferentes nacionalismos coexistirão pacificamente com o liberalismo e expressar-se-ão cada vez mais apenas na esfera da vida privada» ${ }^{109}$. Este mundo pós-histórico terá preocupações essencialmente económicas, tais como «a promoção da competitividade e da inovação, a gestão dos défices internos e externos, a manutenção do pleno emprego, a cooperação perante sérios problemas do meio ambiente, etc.» Será, pois, um mundo com plena consciência de que é herdeiro da revolução burguesa iniciada há cerca de quatro séculos «em que o desejo de uma auto-preservação confortável triunfou sobre o desejo de arriscar a vida numa batalha pelo puro prestígio e onde o reconhecimento racional e universal substituiu a luta pelo domínio» ${ }^{110}$. A razão calculadora surge-nos aqui, pois, na ótica de

109 F. Funuyama, O Fim da História..., op. cit., p. 269.

${ }^{110}$ Ibid., p. 275. 
Fukuyama, como um instrumento de união pacífica entre os homens. Sabe-se, no entanto, que, nos dias de hoje —e utilizando ainda a terminologia de Fukuyama-, o aludido mundo pós-histórico coexiste com um mundo histórico que vive ainda agarrado a mecanismos de legitimidade política — sejam dinásticos, religiosos, nacionalistas ou ideológicos- propensos ao imperialismo e à guerra. Isto implica a necessidade de todas as nações liberais trabalharem em conjunto na promoção da paz internacional, tanto mais quanto, como foi já evidenciado, a guerra no mundo tecnológico se mostrar potencialmente destruidora da Humanidade.

Esta visão filosófica e política que proclama uma união pacífica das nações liberais, revela-se, sem dúvida, herdeira do racionalismo liberal iluminista. Basta evocar a ideia de uma liga internacional de democracias submetidas ao Império do Direito que é quase tão antiga quanto a do próprio liberalismo, pois foi já enunciada por Kant em, pelo menos, dois seus famosos opúsculos, a saber, Ideia de uma História Universal com um propósito cosmopolita (1784) $)^{111}$ e A Paz Perpétua (1795) ${ }^{112}$. E se é certo que os tempos que se seguiram a Kant levaram a um descrédito generalizado do internacionalismo kantiano e do direito internacional, também não é menos verdade, como lembra Francis Fukuyama, que as instituições que se foram criando para a prossecução desses fins — nomeadamente, a Liga das Nações e,

111 Admitindo que os homens «não procedem de modo puramente instintivo, como os animais», mas que também o não fazem «como racionais cidadãos do mundo em conformidade com um plano combinado», Immanuel Kant tenta descobrir, na História, um certo fio condutor, para o que nada mais lhe resta enquanto filósofo «senão inquirir se [...] não poderá descobrir uma intenção da natureza no absurdo do trajecto das coisas humanas, a partir da qual seja possível uma história de criaturas que procedem sem um plano próprio, mas, no entanto, em conformidade com um determinado plano da natureza» [cfr. I. KANT, A Paz Perpétua e outros Opúsculos (tradução portuguesa de Artur Morão da edição original alemã de 1964), Lisboa, Edições 70, 1995, p. 22]. É nesta perspetiva eivada de um certo Historicismo que o filósofo elabora nove proposições tentando perceber a sobredita «intenção da natureza». Na sétima dessas proposições, afirma: «A Natureza utilizou uma vez mais a incompatibilidade dos homens, e até das grandes sociedades e corpos estatais que formam essas grandes criaturas, como meio para encontrar no seu inevitável antagonismo um estado de tranquilidade e segurança; isto é, por meio de guerras, do armamento excessivo e jamais / afrouxado em vista das mesmas, da necessidade que, por fim, cada Estado deve por isso sentir internamente até em tempo de paz, a Natureza compele-os, primeiro, a tentativas imperfeitas e, finalmente, após muitas devastações, naufrágios e até esgotamento interno geral das suas forças, ao intento que a razão lhes poderia ter inspirado, mesmo sem tantas e tão tristes experiências, a saber: sair do estado sem leis dos selvagens e ingressar numa liga dos povos, onde cada Estado, inclusive o mais pequeno, poderia aguardar a sua segurança e o seu direito, não do seu próprio poder ou da própria decisão jurídica, mas apenas dessa grande federação das nações (Foedus Amphictyorum), de uma potência unificada e da decisão segundo leis da vontade unida» (cfr. ibid., p. 30).

112 Veja-se, sobretudo, ibid., pp. 126 e ss. 
posteriormente, as Nações Unidas- não seguiram os preceitos do filósofo ${ }^{113}$. Realmente, em A Paz Perpétua, o «Primeiro Artigo definitivo» estatui que «a Constituição civil em cada Estado deve ser republicana» ${ }^{14}$ —que, em Kant (contrapondo-se à Constituição despótica), expressa, sobretudo, um sistema jurídico-político representativo baseado na separação de poderes— ${ }^{115}$ e o «Segundo Artigo definitivo» determina que «o direito das gentes deve ser fundar-se numa federação de Estados livres» ${ }^{116}$. Ora, desde o seu início —afirma Fukuyama—, «as Nações Unidas não seguiram estas condições. A Carta das Nações Unidas eliminou qualquer referência a uma liga de «nações livres» em favor do princípio mais fraco da «igualdade de soberania de todos os seus membros». Isto é, a admissão nas Nações Unidas ficava possibilitada a qualquer estado que respeitasse determinados critérios mínimos de soberania, quer esta se fundamentasse quer não na soberania popular» ${ }^{117}$. Compreender-se-á, de qualquer modo, que assim tenha acontecido. As democracias liberais desde Kant até hoje não se difundiram no mundo o quantum satis para que uma Liga das Nações livres pudesse almejar uma dimensão universal e, em tal conspecto, verdadeiramente internacional. É certo que depois da II Guerra Mundial e do choque histórico «Auschwitz nunca mais!», as Nações Unidas se responsabilizaram pela proteção dos direitos humanos fundamentais, bem como pela ameaça de castigar as guerras agressivas e os crimes contra a Humanidade. Assim, o que de novo vem ao mundo é catalogado por Ulrich Beck como «revolução inadvertida», pois, bem vistas as coisas, um regime de direitos humanos que adquira prioridade sobre o direito de autodeterminação dos povos, inverte a ordem política mundial. Neste sentido, «los denominados «asuntos internos» de los Estados se convierten en asunto de todos» ${ }^{118}$, abrindo cami-

${ }^{113}$ Cfr. F. Fukuyama, O Fim da História..., op. cit., p. 274.

114 I. Kant, A Paz Perpétua..., op. cit., p. 127.

115 Realmente, ao referir-se a uma Constituição republicana, Kant pretende determinar «o modo de governar o povo, seja quem for o governante», vale por dizer, «a forma de governo (forma regiminis)». Neste sentido, «a constituição é ou republicana ou despótica. O republicanismo - explica Kant- é o princípio político da separação do poder executivo (governo) do legislativo; o despotismo é o princípio da execução / arbitrária pelo Estado de leis que ele a si mesmo deu, por conseguinte, a vontade pública é manejada pelo governante como sua vontade privada»; concretizando, mais adiante: «ao modo de governo que deve ser conforme à ideia de direito pertence o sistema representativo, o único em que é possível um modo de governo republicano e sem o qual todo o governo é despótico e violento» (cfr. ibid., pp. 130 e 132).

116 Ibid., p. 132.

117 F. Fukuyama, O Fim da História..., op. cit., p. 274.

${ }^{118}$ U. BECK, Poder y contrapoder en la era global..., op. cit., p. 110. 
nho para a legitimação intervencionista das forças internacionais em casos de terrorismo estatal contra os próprios cidadãos ou de violações de «direitos cosmopolitas» (Ulrich Beck) por parte dos Estados. O problema que neste particular vai, no entanto, perdurando - como, aliás, o próprio Ulrich Beck não deixa também de aludir-, é que o poder global definidor do que são violações de direitos humanos depende, essencialmente, da força económico-militar dos Estados ${ }^{119}$, dificultando, por conseguinte, a legitimação plena de um organismo que pretendesse que os direitos humanos se sobrepusessem verdadeiramente (isto é, sempre) à soberania dos Estados. Continua a ser, assim, em grande medida (e, não obstante, a influência que ainda perdura do «Auschwitz nunca mais!»), a força e não a lei a comandar os desígnios das relações entre os diversos Estados e organismos internacionais. Estamos, pois, na verdade, muito longe do modelo idealizado por Kant. Mas não será também menos verdade, em nossa perspetiva, que o caminho a seguir pela via pacífica seja precisamente o de conseguir que as democracias liberais se espalhem de tal forma pelo mundo que se consiga uma Liga das Nações preocupada, fundamentalmente, com a proteção dos direitos fundamentais. E que, nesse quadro, uma eventual intervenção jurídico-militar por desrespeito desses direitos, opere de forma imparcial, isto é, segundo pressupostos sancionatórios gerais e abstratos e não segundo os desígnios e interesses dos Estados jurídico-militarmente mais fortes. Será, efetivamente, este o caminho a seguir e que se antolha como o grande desafio atual da Humanidade: atuar sempre, em si, como se esse objetivo fosse possível $^{120}$. Não que se defenda aqui que o fluir para as democracias liberais em todo o mundo resulte de uma perspetiva de fechado Historicismo dialético na evolução da História do Poder Político, ao jeito hegeliano ${ }^{121}$.

${ }_{119}$ Cfr. ibid.

${ }^{120}$ O próprio Kant tem consciência de que a paz perpétua se possa revelar um objectivo irrealizável, não deixando porém de considerar que, ainda assim, se deve agir em vista do seu estabelecimento, como se a coisa fosse o que porventura não é, vale por dizer, aceitando a máxima de agir continuamente nessa direção (veja-se, por exemplo, I. KANT, Die Metaphysik der Sitten, Sttutgart, Reclam, 1990, I, $\mathbb{S} 62$ ). E, realmente, ainda que esse objetivo final seja de uma dificuldade extrema ou mesmo inatingível em um estádio próximo da perfeição, o caminho a seguir referido parece-nos, no entanto, o único a considerar se a humanidade quiser ter futuro. Sobre as dificuldades práticas (e também teóricas) da imposição (ou da consagração) de um direito cosmopolita alicerçado na protecção dos direitos humanos fundamentais, sobretudo no que toca aos contrapoderes que, inevitavelmente, se vão formando na senda da concretização de um projeto cosmopolita, veja-se, por exemplo, U. BECK, Poder y contrapoder en la era global..., op. cit., pp. 387 e ss.

121 Até porque, ainda que se possa admitir que o caminho histórico da dialéctica hegeliana seja em direcção às democracias liberais, como o faz Fukuyama, para Hegel «a liberdade não é livre arbítrio do indivíduo» [cfr. J. Hyppolite, Introdução à Filosofia da História 
Realmente, não se segue aqui uma visão, em termos de percurso histórico-social, de um certo iluminismo de pensamento marcadamente sistemático que, abdicando do «inteligir problemático» (Faria Costa), se cingia «a uma lógica a que, por exemplo, Augusto Comte, Hegel e Marx» emprestavam, «a diferentes luzes, a força de uma razão raisonnante» e «à qual se juntava a harmonia da totalidade, concebida como um templo sagrado de que se excomungava, inapelavelmente, o ruído surdo da dissonância» ${ }^{122}$.

Todavia, como afirma Karl Popper, se «a História [...] não tem sentido», isso «não implica que tudo quanto possamos fazer a tal respeito seja olharmos consternados para a História do poder político, ou que a encaremos como uma cruel ironia». De facto, «podemos interpretar a História do poder político do ponto de vista da luta pela sociedade aberta, por um regime da razão, pela justiça, igualdade, liberdade e pelo controlo do crime internacional. Embora a História não tenha objectivos, podemos impor- lhes os nossos; e embora a História não tenha um sentido, podemos dar-lhe um sentido» ${ }^{123}$. Popper refuta, pois, as teorias historicistas na medida em que estas conduzam (e para Popper conduzirão sempre) a teorias políticas utópicas que tentam mudar prontamente (e artificialmente) as sociedades e estabelecer uma espécie de Estado ideal em que as instituições são necessária e cegamente adaptadas ao determinismo histórico-ideológico que preconizam. Na prática redunda-se, invariavelmente, no estabelecimento de sociedades fechadas (sobretudo protegidas da mudança que tenta subverter aquele determinismo histórico-ideológico), autoritárias e totalitárias. Mas quando advoga a sociedade aberta na qual as instituições políticas podem ser modificadas pelos governados e onde é dada a maior liberdade política ao pensamento, ao criticismo e à experimentação política, Popper defende, seguramente, um sentido que o livre arbítrio dos seres humanos pode emprestar à História, qual seja o do rumo para as democracias liberais. E a verdade é que as populações, na sua génese, se mostram mais favoráveis, tudo o indica, às democracias liberais, tornando-se, assim, legítimo esperar que elas se expandam pelo mundo e que no futuro, no mundo globalizado, o direito internacional possa vir a ser, como pretendia Kant, o direito interno aplicado extensivamente (o mesmo será dizer, no limite, que o mundo globalizado, voltamos a insistir, possa ter futuro).

de Hegel (tradução portuguesa de José Marcos Lima da edição original francesa, s.d.), Lisboa, Edições 70, 1995, p. 31].

122 J. F. de F. Costa, Linhas de Direito Penal e Filosofia..., op. cit., p. 11.

${ }^{123}$ K. Popper, A Sociedade Aberta e os seus Inimigos [tradução portuguesa de Teresa Curvelo da 5.. edição original alemã de 1966], vol. II, Lisboa, Fragmentos, 1993, p. 272. 
Nota-se aqui, pois, uma sintonia entre Popper e Kant, na medida em que o «provinciano universal» de Könisberg negava também «a possibilidade de descobrir na História uma ordem harmónica e progressiva, um desenvolvimento natural e contínuo de todas as potências do espírito» ${ }^{124}$, afastando-se, pois, da ideia de um fechado historicismo determinista. O caminho para Kant era, ao invés, o do livre arbítrio, fundado na ideia de que a tendência natural do ser humano «é a de alcançar a felicidade ou a perfeição através do uso da razão, o mesmo é dizer, através da liberdade» ${ }^{125}$. Ora, no entendimento de Kant, o ser humano só pode alcançá-las verdadeiramente «numa sociedade política universal, na qual a liberdade de cada um não encontre outro limite senão a liberdade dos outros» ${ }^{126}$. E é nesta linha de pensamento, assente em pressupostos alicerçados na liberdade humana, que Kant fundamenta o seu direito cosmopolita mundial. Sabe-se, é verdade, que, nos dias de hoje, invocar Kant é correr o risco de suscitar juízos de reprovação fundados em preconceitos pós-modernos de índole desconstrucionista que sobretudo apontam criticamente o carácter necessário e universal que o filósofo de Könisberg imprime às conclusivas da sua doutrina racional pura. Mas seria realmente irónico e paradoxal — como de resto assinala Ulrich Beck- que o pai da paz perpétua e do direito cosmopolista mundial fosse afastado do pensamento filosófico-político da sociedade global ${ }^{127}$. E se, realmente, como ainda hoje se constata, nos encontramos longe do modelo ideal de Kant, Ulrich Beck sempre vai afirmando que o caminho nesse sentido tem vindo a ser trilhado e já resistiu mesmo a duas posições filosófico-políticas que, historicamente, se revelaram erradas, a saber, marxismo e pós-modernismo ${ }^{128}$. Mas, se ainda assim, se qui-

${ }^{124}$ N. Abbagnano, História da Filosofia [tradução portuguesa de António Ramos Rosa da edição original italiana, s.d.], vol. VI, 2.. ${ }^{a}$ ed., Lisboa, Presença, 1977, p. 167.

${ }^{125}$ Ibid.

126 Ibid., p. 168.

${ }^{127}$ Cfr. U. BECK, «A Sociedade Global do Risco (uma discussão entre Ulrich Beck e Danilo Zolo)», disponível na Internet em bttp://www.cfh.ufsc.br/ wfil/ulrich.btm, p. 8.

${ }^{128}$ Concretizando, afirma Beck que o ponto de vista marxista de que todas as concepções jurídicas são, em última análise, burguesas — razão pela qual se deve descartar política e moralmente o universalismo dos direitos humanos como cimento e meta de atuação política-, deve ser refutado não só porque se não dá conta de que os direitos humanos universais, na sua importância moral, política e estratégica se reforçam entre si, mas também porque se trata de um ponto de vista que «contradice escandalosamente el internacionalismo obrero». Já quanto ao ponto de vista pós-moderno segundo o qual os direitos humanos seriam fruto tardio de uma Ilustração que se revelou um grande erro de consequências imperialistas, na medida em que o imperialismo intrínseco à universalidade do regime dos direitos humanos entraria em aberta contradição com um mundo de diferenças culturais, a questão revela-se um pouco mais complexa, devido, talvez —ou também—, ao facto 
ser persistir no preconceito de negar o Iluminismo, de negar Kant, Rawls e muitos outros, lembremo-nos que os valores universais invocados não se justificam apenas em si, revelando-se também —e sobretudo- instrumentais e necessários à sobrevivência da Humanidade; e que não os fundamentar com esse carácter universal poderá ser o contributo para o desenho de um futuro que regresse a uma espécie de pré-iluminismo, ou, empregando expressões já por nós utilizadas, a uma sorte de neoabsolutismo ou mesmo a um modelo de Estado neoconfessional. E isso poder-se-ia revelar catastrófico. Sem se cair na teoria das histórias cíclicas de povos específicos — característica da historiografia grega e romana e retomada, de certa forma, por historiadores como Spengler e Toynbee-, a verdade é que, ao não se enveredar por um exasperado historicismo se aceita uma História com diversos elementos cíclicos também ao nível do pensamento político ou filosófico, nomeadamente quando essa mesma História é completamente ignorada e esquecida pelos seres humanos gerando equívocos e incompreensões do presente.

«"O mundo está a aproximar-se velozmente do fim”, assim disse o arcebispo Wulfstan, num sermão proferido em York [...] no ano 1014» ${ }^{129}$.

\section{BIBLIOGRAFIA}

Abbagnano, N., História da Filosofia [tradução portuguesa de António Ramos Rosa da edição original italiana, s.d.], vol. VI, 2.. ${ }^{a}$ ed., Lisboa, Presença, 1977. Anderson, P., As Origens da Pós-Modernidade [tradução portuguesa de Marcus

Penchel da edição original inglesa de 1998], Rio de Janeiro, Zahar, 1999.

Baudrillard, J., A Sociedade de Consumo [tradução portuguesa de Artur Morão

da edição original francesa, s.d.], Lisboa, Edições 70, 2010.

de se tratar de uma perspectiva mais recente. Sem embargo, como denota Ulrich Beck, estas diferenças culturais não só dificultam a comunicação entre os povos, como muitas vezes a excluem, denegando, portanto, consequentemente, o horizonte comum dos «direitos humanos». Na verdade, utilizando as palavras do sociólogo alemão, «al pensamiento posmoderno, la pretensión de crear horizontes de expectativas normativos y vinculantes para todos a través del régimen cosmopolita de los derechos humanos le suscita las más graves sospechas, le parece un vehículo para la represión y para la dominancia exclusiva de las pretensiones de una cultura sobre de las otras. La objeción — concretiza Beck- de que los derechos humanos, así como el régimen cosmopolita general, sientan precisamente el derecho de ser diferente, contradice abiertamente al posmodernismo, cuestiona con energía el dogmático relativismo posmoderno» (cfr. U. BECK, Poder y contrapoder en la era global..., op. cit., p. 392).

129 A. GidDEns, O Mundo na Era da Globalização [tradução portuguesa de Saul Barata da edição original inglesa de 1999], Lisboa, Presença, 2000, p. 15. 
BECK, U., La sociedad del riesgo. Hacia una nueva modernidad [tradução castelhana de Jorge Navarro, Daniel Jiménez e Rosa Borrás da edição original alemã de 1986], Barcelona, Paidós, 1998.

- Poder y contrapoder en la era global. La nueva economía política mundial [tradução castelhana de R. S. Carbó da edição original alemã de 2002], Barcelona, Paidós, 2004.

- «A Sociedade Global do Risco (uma discussão entre Ulrich Beck e Danilo Zolo)», disponível na Internet em bttp://www.cfh.ufsc.br/ wfil/ulrich.btm (acedido em 13 de Abril de 2006).

- ¿Qué es la globalización? Falacias del globalismo, respuestas a la globalización, Barcelona, Paidós, 2008.

Berlin, I., Rousseau e outros cinco inimigos da liberdade [tradução portuguesa de Tiago Araújo da edição original inglesa de 2002], Lisboa, Gradiva, 2005.

Bermejo, D., Posmodernidad: pluralidad y transversalidad, Barcelona, Antrophos, 2005.

Borges, A. de, «O crime económico na perspectiva filosófico-teológica», RPCC, 10 (2000), pp. 9 e ss.

Costa, J. F. de F., Linhas de Direito Penal e de Filosofia: alguns cruzamentos reflexivos, Coimbra, Coimbra Editora, 2005, pp. 9 e ss.

Dias, Jorge de F., Direito Penal - Parte Geral. Questões Fundamentais. A Doutrina Geral do Crime, t. I, 2.. ${ }^{\text {e }}$ ed., Coimbra, Coimbra Editora, reimpressão, 2012.

Franco, L., A Crise do Mundo Moderno, Lisboa, Pro Domo, 1945.

Fukuyama, F., O Fim da História e o Último Homem [tradução portuguesa de Maria Goes da edição original inglesa de 1992], 2.. a ed., Lisboa, Gradiva, 1999.

Giddens, A., O Mundo na Era da Globalização [tradução portuguesa de Saul Barata da edição original inglesa de 1999], Lisboa, Presença, 2000.

Habermas, J., Técnica e Ciência como «Ideologia» [tradução portuguesa de Artur Morão da edição original alemã de 1968], Lisboa, Edições 70, 1994.

- O Discurso Filosófico da Modernidade [tradução portuguesa de Luiz Sérgio Repa e Rodnei Nascimento da edição original alemã de 1985], São Paulo, Martins Fontes, 2002.

- Racionalidade e Comunicação [tradução portuguesa de Paulo Rodrigues da versão original alemã de 1976], Lisboa, Biblioteca de Filosofia Contem, 2002.

Hyppolite, J., Introdução à Filosofia da História de Hegel [tradução portuguesa de José Marcos Lima da edição original francesa, s.d.], Lisboa, Edições 70, 1995.

JAMESON, F., «Pós-modernidade e sociedade de consumo» [tradução portuguesa de Vinicius Dantas da versão original inglesa], Novos estudos, 12 (1985), pp. 16 e ss.

Jỗo Paulo II, A Fé e a Razão (carta encíclica Fides et Ratio), 4.. a ed., Lisboa, Edições Paulinas, 2003.

JonAs, H., Le Principe Responsabilité. Une éthique pour la civilisation technologique [tradução francesa de Jean Greish da edição original alemã de 1979], Paris, Flamarion, 2001. 
Kant, I., Crítica da Razão Prática [tradução portuguesa de Artur Morão da edição original alemã de 1788], Lisboa, Edições 70, 1989.

- Die Metaphysik der Sitten, Stuttgart, Reclam, 1990.

- A Paz Perpétua e outros Opúsculos [tradução portuguesa de Artur Morão da edição original alemã de 1964], Lisboa, Edições 70, 1995.

- Grundlegung zur Metaphysik der Sitten, Sttutgart, Reclam, 1996.

Mendes, P. de S., Vale a pena o direito penal do ambiente?, Lisboa, AAFDL, 2000.

- O torto intrinsecamente culposo como condição necessária da imputação da pena, Coimbra, Coimbra Editora, 2007.

MiLl, J. S., Utilitarismo [tradução portuguesa de Azevedo Gonçalves da 4.. edição original inglesa de 1871], Lisboa, Gradiva, 2005.

Neiman, S., O Mal no Pensamento Moderno. Uma História Alternativa da Filosofia [tradução portuguesa de Vítor Matos da edição original inglesa de 2002], 1.. ${ }^{a}$ ed., Lisboa, Gradiva, 2005.

Nietzsche, F., O Nascimento da Tragédia ou Mundo Grego e Pessimismo [tradução portuguesa de Teresa Cadete da edição original alemã de 1872], Lisboa, Relógio D’Água Editores, 1977.

- Assim Falava Zaratustra. Livro para todos e para ninguém [tradução portuguesa de Carlos Grifo Babo da edição original alemã, s.d.], 4.. ${ }^{a}$ ed., Lisboa, Presença, 1978.

Popper, K., A Sociedade Aberta e os seus Inimigos [tradução portuguesa de Teresa Curvelo da 5.." edição original alemã de 1966], vol. II, Lisboa, Fragmentos, 1993.

- Um Mundo de Propensões [tradução portuguesa de Teresa Barreiros e Rui Feijó da edição original alemã, s.d.], Lisboa, Fragmentos, 1991.

- O Universo Aberto: pós-escrito à lógica da descoberta científica [tradução portuguesa de Nuno Ferreira da Fonseca da edição original alemã de 1983], vol. II, Lisboa, Publicações Dom Quixote, 1992.

- Sociedade Aberta, Universo Aberto (entrevista conduzida por Franz Kreuzer em 1979) [tradução portuguesa de Maria Helena Rodrigues Carvalho da edição original alemã de 1982], Lisboa, Publicações Dom Quixote, 1995.

Popper, K., e Lorenz, K., O Futuro Está Aberto [tradução portuguesa de Teresa Curvelo da edição original alemã de 1983], 2.. ${ }^{a}$ ed., Lisboa, Fragmentos, 1990.

Rawls, J., Uma Teoria da Justiça [tradução portuguesa de Carlos Pinto Correia da edição original inglesa de 1971], Lisboa, Presença, 1993.

- Sobre las libertades [tradução castelhana de Jorge Vigil Rubio da edição original inglesa de 1982], Barcelona, Paidós, 1996.

- Justiça como Eqüidade: uma reformulação [tradução portuguesa de Cláudia Berliner da edição original inglesa de 2002], São Paulo, Martins Fontes, 2003.

SANDEL, M., O Liberalismo e os Limites da Justiça [tradução portuguesa de Carlos Pacheco do Amaral da edição original inglesa de 1998], Lisboa, Fundação Calouste Gulbenkian, 2005. 
Santos, B. S., Pela Mão de Alice. O Social e o Político na Pós-Modernidade, 7... ed., Porto, Edições Afrontamento, 1999.

- A crítica da razão indolente: contra o desperdício da experiência [Para um novo senso comum. A ciência, o direito e a política na transição paradigmática], vol. I, 2.. ${ }^{a}$ ed., Porto, Edições Afrontamento, 2002.

Silva Sánchez, J. M., La expansión del Derecho penal. Aspectos de la política criminal en las sociedades posindustriales, Madrid, Edisofer, 2011, p. 22.

Torrão, F., «Os novos campos de aplicação do direito penal e o paradigma da mínima intervenção», Liber Discipulorum para Jorge de Figueiredo Dias, Coimbra, Coimbra Editora, 2003, pp. 331 e ss.

- «A responsabilidade do comitente (algumas considerações a partir de um caso concreto)», Lusíada. Direito. Porto, núm. 1 e 2 (1999), pp. 33 e ss.

Touraine, A., Crítica da Modernidade [tradução portuguesa de Fátima Gaspar e Carlos Gaspar da edição original francesa de 1992], Lisboa, Instituto Piaget, 1994.

Weber, M., A Ética Protestante e o Espírito do Capitalismo [tradução portuguesa de Ana Falcão Bastos e Luís Leitão da edição original alemã, s.d.], 5... ed., Lisboa, Presença, 2001. 